\title{
Barber's World of Birds As a Space of Gender Equality
}

From at least the end of the eighteenth century, English-speaking intellectuals had become interested in the social lives of birds. While less than one per cent of all known species of animals are birds, they are one of the most relevant groups of animals with which humans can compare their own social relationships. ${ }^{1}$ Birds had long served as metaphors for humans due to their social structures and sense of community which have been regarded as independent from, yet homologous with, those of human societies. ${ }^{2}$

Authors and philosophers had been employing images of caged birds to voice their concerns about the subordinate position of women in society. In A Vindication of the Rights of Women (1792), the English writer and philosopher Mary Wollstonecraft, for instance, objected that women who were treated like caged birds were left with nothing to do other than to adorn themselves and gossip. ${ }^{3}$ For Olive Schreiner, writing about a century later in the Cape, women were similarly constrained, which in turn raised the rhetorical question of why they had to be trapped in metaphorical cages if, as men were apt to claim, women were satisfied with their situation. ${ }^{4}$

Barber, in a poem published one year before her death, with customary dry humour, used a bird metaphor to demand that men granted their wives more independence. During her childhood, she and her younger sister were almost as free to follow their own interests as their nine brothers. By the time she was eighteen, gender roles within the settler community in Albany had become more deeply entrenched as the local settler population

(C) The Author(s) 2019

T. Hammel, Shaping Natural History and Settler Society, Cambridge Imperial and Post-Colonial Studies Series, https://doi.org/10.1007/978-3-030-22639-8_8 
grew. Settlers sought to provide a model for the amaXhosa to imitate the gendered division of labour commonly practised in Britain. ${ }^{5}$ Despite this changing social climate with narrowing opportunities for women to follow their own interests, Barber continued to carve out a space for herself to pursue her passion of science. Yet, she encountered difficulties which is why she encouraged men to support their wives. In her 1898 poem, she played with a well-known proverb that she reversed, as she did with a series of similar sayings in other contexts, to prove them wrong.

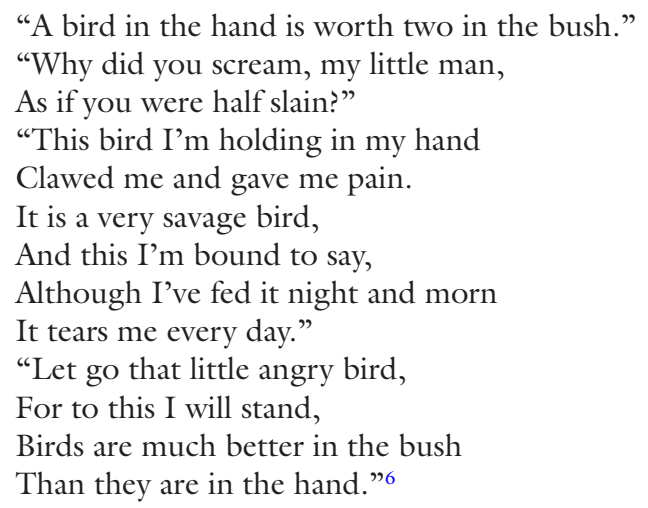

Here, Barber directly addresses a man complaining about the pain he had experienced through his 'bird in the hand', his wife. The man wonders what he did wrong, having fed his wife and given her all that he thought she needed. Barber advises him not to constrain her but to give her freedom and independence, by acknowledging that women are equal to men, have identical needs and are much happier when treated accordingly.

Barber's approach differed from that of feminist writers and naturalists' practices at the time. Unlike feminist writers, she-as the first woman ornithologist in South Africa-included ornithological information in her metaphorical descriptions of the social position of women. Yet, I am not interested in the scientific validity of her ornithological descriptions or her contribution to ornithology (see Chap. 4), but in what she observed in the bird world around her that her colleagues did not see. Naturalists had developed two main strategies to voice their social concerns through the 
description of non-human animals: anthropomorphism and zoomorphism. The former was particularly popular, as, for instance, the popular children's stories by Beatrix Potter show. ${ }^{7}$ Darwin's philosophy, on the other hand, was zoomorphism. ${ }^{8} \mathrm{He}$ was convinced that 'all human traits could be found to some degree in animals', which made him emphasise 'the animal nature of humans, not vice versa'. ${ }^{9}$ While Barber's work shows tendencies of both, ${ }^{10}$ she did not anthropomorphise birds but present them as homologues.

Barber by her own admission 'on all occasions made a point of taking the part of [her] sex'. ${ }^{11}$ Some feminist scientists at the time abandoned their scientific careers to advocate for an end to women's exclusion from science, such as the botanist, astronomer and leader in the early British suffrage movement Lydia Ernestine Becker (1827-1890). ${ }^{12}$ Others did not voice their opinion on women's role in society for their careers in science, such as Mary Treat. Barber was eager to empower women, promote their self-confidence and show her compatriots what women could achieve in men-dominated domains such as science. Barber's colleagues, in contrast, have hitherto either presented themselves or been portrayed by memoirists and historians as being reliant on men scientists, such as the English economic entomologist Eleanor Anne Ormerod. ${ }^{13}$

This chapter provides a detailed exploration of Barber's scientific feminism. Many influential studies investigating the intersectionality of gender, race and class, have studied the historical construction of white femininity in a racist society. ${ }^{14}$ In these studies, feminists were women who pursued their careers as doctors, and later anthropologists, at the Cape, and showed an interest in other women's lives and adversities. ${ }^{15}$ The subjects of these studies, however, did not voice their opinions in regard to a woman's social and scientific position. ${ }^{16}$ This creates the false impression that there were no women advocating for gender equality at the time, which is why more studies are needed. Indeed, one may be led to believe that among her contemporaries Barber was an exception in her ideology. Yet, this was not the case as a critical reexamination of cases in other parts of the world shows. It is my contention that scientific feminism was more widespread among women scientists than hitherto thought.

Barber's interest in ornithology had blossomed from 1862 onwards, when she began painting a series of South African birds. ${ }^{17}$ In these illustrations, she did not follow the conventional bird iconography, pioneered by the French naturalist Georges-Louis Leclerc, Comte de Buffon 
(1707-1788), which emphasised the appearance of male birds and the classificatory importance of the species' habitats. ${ }^{18}$ Barber, in contrast, focussed equally on the male and female of every species she studied. ${ }^{19}$ Similarly, her descriptions of birds in her correspondence with Layard also transgressed conventions. ${ }^{20}$

Through her ornithological descriptions and depictions, she created what a century later the theorist of media, visual art and literature W. J. T. Mitchell would call an 'imagetext'. ${ }^{21}$ Barber combined images and texts that supplemented each other, so that her aquarelles were not merely for illustrative purposes. On the contrary, she emphasised illustrations' importance in her work out of a conviction that visuals could provide information which language could not, allowing her to present evidence useful for addressing and convincing a non-specialist audience in distant parts of the globe. I then reconstruct her intended imagetexts and provide a comparative, intervisual and intertextual analysis contextualised within contemporary ornithological practices. ${ }^{22}$ As in Part I, I draw attention to the potential of critically analysing visual sources to shed light on issues otherwise unvoiced-in this case how ornithologists articulated social critique in their scientific illustrations.

Avifauna-the world of birds - was simultaneously a human-made, physical space and a mental concept which was both homologous with and metaphorical for, but in many ways diametrically opposed to, Cape settler society. Unlike Foucault's heterotopias which have a material correspondent in the real world, ${ }^{23}$ the reality of this correspondent radically diverges as differences emerge which render them as counter-places to ordinary social spaces. Through counter-places, a tension-filled relationship with the dominant culture and its spatial order is enacted. The territory of avifauna is defined in opposition to the cultural sphere, but at the same time has to correlate with it. Unlike a national park or Foucault's examples of heterotopias such as boats and brothels, avifauna is mostly envisioned as a space destitute of human beings. Barber did not turn the bird world per se into a counter space; through her imagetext, she created a space of difference on paper and could thus conceptualise a utopian, gender-equal society by describing and depicting the local bird world. 


\section{Egalitarian Parenting and Biological Equality}

Barber paid more attention to nurturing among birds than other ornithologists at the time. To challenge the perception that childrearing was the natural duty of women, Barber accentuated the egalitarian division of labour practised by birds while rearing their young. Ostriches, for instance, were said to partner equally: the female ostrich protected her eggs or young during the day, before the male took over at night, a pattern of behaviour which she claimed also explained their respective brown and black plumage. ${ }^{24}$ According to Barber, male sunbirds, Cape canaries, yellow finches and red sparrows, meanwhile, performed a full share of the laborious duties involved in nest-building and the rearing of their young. Barber went on to emphasise that while the male of these species assisted the female in numerous ways, partner birds did not necessarily perform the same tasks. Yet, they always divided their labour equally. Among the sunbirds, Barber noted with interest, the male looked after young females, while the female reared young males. ${ }^{25}$ In other instances, she used the term 'parent bird' ${ }^{26}$ without indicating whether a bird was female or male, to emphasise their equality. To demand equal parenting was extremely unusual in the mid-nineteenth century.

The ideal woman at the time was portrayed as 'the Angel in the House'. The expression comes from the narrative poem The Angel in the House by Coventry Patmore, first published in 1854 and expanded until 1862. The term came to be used in reference to women who embodied the Victorian feminine ideal: a wife and mother who was selflessly devoted to her children, submissive to her husband and found fulfilment in the domestic sphere. ${ }^{27}$ The anthropologist Ann Stoler has observed that childbearing in the nineteenth century was seen as 'a national, imperial, and racial duty' with motherhood standing 'at the centre of empire-building' ${ }^{28}$

While pioneers in the women's rights movement, particularly in England, underlined the special skills of women in the realms of childcare, healthcare, education and domestic morality rather than emphasising women's similarity to men, ${ }^{29}$ Barber lamented her husband's lack of participation in raising their children, which would have allowed her more time for her own scientific pursuits. In a letter to her sister-in-law in 1854, she complained that she felt like 'the old woman that lived in the shoe' as her three children demanded the majority of her precious time to the extent that she felt she 'often waste[d] time in talking and playing with them that [she] might employ otherwise'. ${ }^{30}$ In her unconventional 
description of her child-rearing activities, she criticised the prevailing Aristotelian view that women were passive vessels for the foetus, that maternal instincts determined a woman's character and that maternity and caregiving were the duty and sole source of fulfilment for women. ${ }^{31}$ She barely mentioned her children, Frederick Hugh, Henry Mitford and Mary Ellen, in her scientific correspondence, unlike even Hooker and Darwin. ${ }^{32}$ Unlike many colonial white women, she seems not to have had African servants to assist her with these supposedly women's duties.

Barber criticised the constraints of domesticity through the example of hornbills: these birds used mud and sticks to build their nests in old, damaged or hollow trees so that during incubation the female would be trapped in the nest by the male who closed the entrance in such a way that it became impossible for her to escape, leaving only a small hole through which to feed his mate during her lengthy confinement. Barber did not know the duration of the female hornbill's 'imprisonment', but described how she found the females to be cramped, weak and unable to fly when she freed them. Nevertheless, she believed that there had to be a reasonable cause for the male's behaviour, such as to help his mate survive at a time when she was too weak to defend herself. In the case of human couples, however, she could find no explanation for similar behaviour beyond the stubbornness and arrogance of men, which led them to act irrationally and thoughtlessly by confining women to a world of household chores and parenting. ${ }^{33}$ Barber's empathetic description indicates that she felt imprisoned by her own situation in which she, like the female hornbill, was forced to remain at home with her children, while her husband could venture off to wherever he wanted.

Barber repudiated the existence of gender personae ${ }^{34}$ and sought to prove their non-existence with observations of stereotypically femaleassociated behaviour in male birds and vice versa. The female Cape bristlenecked thrush, for instance, protected her mate and uttered a piercing cry when warning him of any nearby danger. For Barber, this example illustrated that female birds-like women-could act independently of their mates and were capable of protecting both themselves and others. She also highlighted the female thrush's low and cawing notes which resembled those of a frog and thereby challenged the notion that female organisms had high-pitched voices. ${ }^{35}$

Through descriptions of male birds, she criticised the paternalistic behaviour of men. In 1868, she described two rare African birds, specimens of which she had borrowed from Edwin Atherstone's Albany 
Museum collection. One was 'a military character in a scarlet and black and green uniform' with 'a proud overbearing look', while the other 'must have been in his own country a great King for he wore an imperial purple shot with gold and blue'. ${ }^{36}$ This is one of her many side-comments in letters through which she, on the one hand, described what she was currently working on, and, on the other, anthropomorphised birds. By describing them as military and royal characters, she humorously, yet critically, reflected on patriarchal structures which she saw mirrored in their appearance. Similarly, she ridiculed the chirping of the male buff-streaked chat as merely a means to annoy or amuse his mate. According to Barber, this type of bird-keen on positioning himself upon elevated rocks that enabled him to overlook his surroundings and to make himself visible by twittering, opening and shutting his wings, and 'bowing and scarping'-thought 'no end of himself'. ${ }^{37}$ She thereby registered her disapproval of showmanship and scorned the male's desperate attempts to be chosen by the powerful female, who-she emphasised-enjoyed ultimate power over her male counterparts.

Barber was particularly interested in describing and depicting species which exhibit only a slight degree of sexual dimorphism, such as the South African hoopoe, to emphasise gender equality. These barely visible differences between males and females of some species usually consisted in only a slightly smaller size or shorter wingspan, bill or crest in one sex or in faint alterations in colour between the sexes. Of the eleven remaining undated ornithological watercolours held in the Art Store at the History Museum of the Albany Museum Complex, there are three bird pairs depicted with their nest and eggs, two pairs with only their nest, two same-sex birds (one male, one female) sitting on a branch and one bird depicted killing a member of another species of bird without any reference to the sex of either. ${ }^{38}$ Presumably, some of these were those seen by Emil Holub in Kimberley, from which it can be assumed that she painted these in the 1860s or 1870s, when she collaborated with Layard. Slight sexual dimorphism is depicted in five of the watercolours - exactly half of the paintings which include more than one bird of the same species - and their accompanying notes, but the negligible nature of these differences is highlighted. Among other species, Barber observes no perceivable difference in appearance between males and females as she informed Layard. ${ }^{39}$

Barber's depiction of the bird world as a space of gender equality must be seen in the context of contemporary discourse on gender relations in ornithology. In the British ornithologist John Gould's (1804-1881) The 
Birds of Great Britain (1862-1873), bird families were shown in their nests. In contrast, nests had rarely been depicted in the plates of Audubon, who is widely regarded as having set the standards for bird iconography. In the exceptional cases when nests were included in his illustrations, Audubon emphasised nest construction, but ignored the role nests had as the domestic setting for the rearing of offspring. ${ }^{40}$ In contrast, Gould visualised monogamous domesticity and familial harmony rather than intrasexual competition, sexual display or female choice.

Gould had already adopted this strategy in Birds of Australia (1840-1848), ${ }^{41}$ but further developed and bolstered it with reference to Darwin's publications and the concomitant discourse on females' place in nature. ${ }^{42}$ His studies on Australian birds increased his fame thanks to the ground-breaking illustrations of his wife. Elizabeth Gould started including young birds in her illustrations, most likely as a result of missing her young children, whom she had to leave behind in England while she accompanied her husband to Australia. ${ }^{43}$ Elizabeth died shortly after their return in 1841, after the birth of their seventh child. ${ }^{44}$ Gould then turned his focus to British birds. The untimely death of his wife may have influenced him to follow this new direction to be close to his children. The prospect of the undertaking of a patriotic project at the height of his career, however, must have piqued his interest. As British birds had already been well-documented, he was forced to think of innovative strategies, such as illustrating the brood. By frequently depicting females near their nests, incubating, protecting, feeding or hovering over their offspring while males stood or perched to the side, he provided new information on British birds while reinforcing the idea of separate spheres through his influential illustrations. In the process, he naturalised the culturally constructed gender stereotypes and family norms shared by his readership, who were mainly drawn from the conservative gentry. ${ }^{45}$

While Gould reinforced the Victorian gender values that Darwin had applied to birds as 'facts of nature rather than constructions of culture', ${ }^{46}$ he envisioned an (ornithological) world in which neither natural nor sexual selection were at work. He thereby aimed to challenge Darwin's vision of nature which, Gould believed, had disrupted notions of gender roles, as sexual selection empowered females and women and considerably enlarged their scope of action. Instead of the act of sexual reproduction, he depicted 'married couples', nests, eggs and young birds, while stressing the fixity of species and the 'wisdom, power, and the beneficence of [the] Creator'. ${ }^{47}$ 
A comparison of Barber and Gould's respective ornithological illustrations is revealing in terms of the radically different family lives they imagined for humans. Figure 8.1 shows a female and male redwing by Gould, native to Europe and Asia. Both sexes look similar: plain brown backs, dark brown spots on beige underparts, red flanks and underwings as well as fawn-coloured stripes above the eye. The female protects the nest with its four eggs, while the male is observing her from a distance, as if suggesting the female bird was in the domestic and the male in the public sphere.

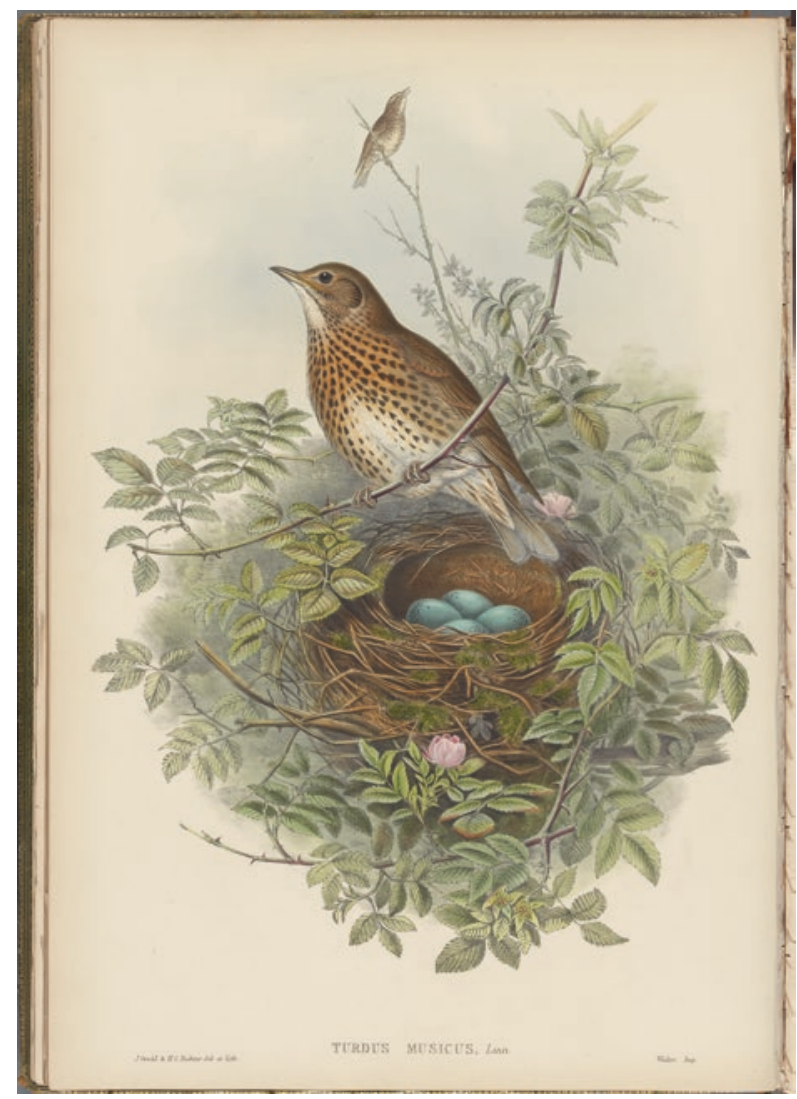

Fig. 8.1 Turdus musicus, thrush, Gould's The Birds of Great Britain, 1862-1873, hand-coloured lithograph. (C) Rare Books Division, The New York Public Library, Astor, Lenox and Tilden Foundations) 


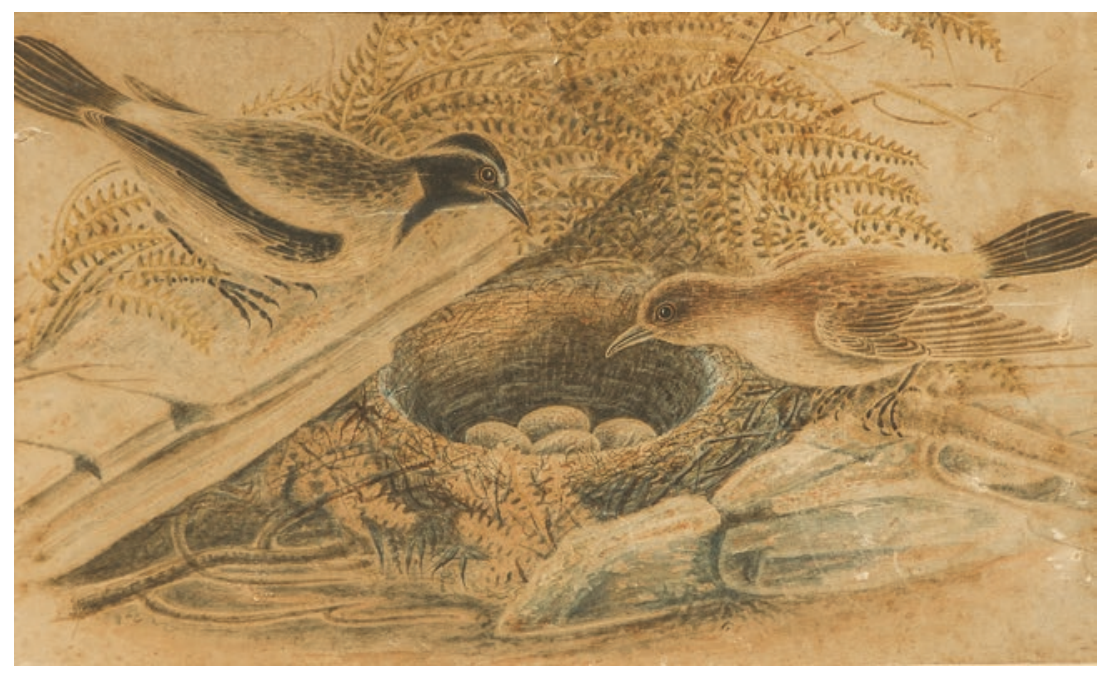

Fig. 8.2 Myrmecocichla bifasciata, male and female. ( History Museum, Albany Museum Complex, Art Store no 7, photographed by Paul Greenway, P3 Photography, December 2015. All rights reserved)

Figure 8.2 is Barber's depiction of a female and male buff-streaked chat, endemic to South Africa, Lesotho and Swaziland in areas of dry lowland and rocky, sour grassland. The male has a black throat and upper breast. The rump and underparts, the wing underside, are buff-coloured. The female's underparts are lighter. ${ }^{48}$ The male and female are almost of equal size and height, positioned on eye-level and share child-rearing duties. While Gould naturalised Victorian gender roles, Barber exposed them for cultural constructs in her depictions of birds.

Comparing Barber's illustration to her written descriptions discussed above shows that the visual and the textual elements complemented one another. While she criticises male chauvinistic behaviour in her texts, she depicts birds of both sexes equally, sharing child-rearing duties, in her illustration. The imagetext she created thus allows her to reject the Victorian gender roles that Gould projected onto birds.

A comparison of Gould's illustration of the male and female European roller (Coracias garrulous) (Fig. 8.3) with that by Barber (Fig. 8.4) is equally meaningful. The European roller breeds in the Western, Southern and Central Palaearctic, before usually wintering in the dry, wooded, 


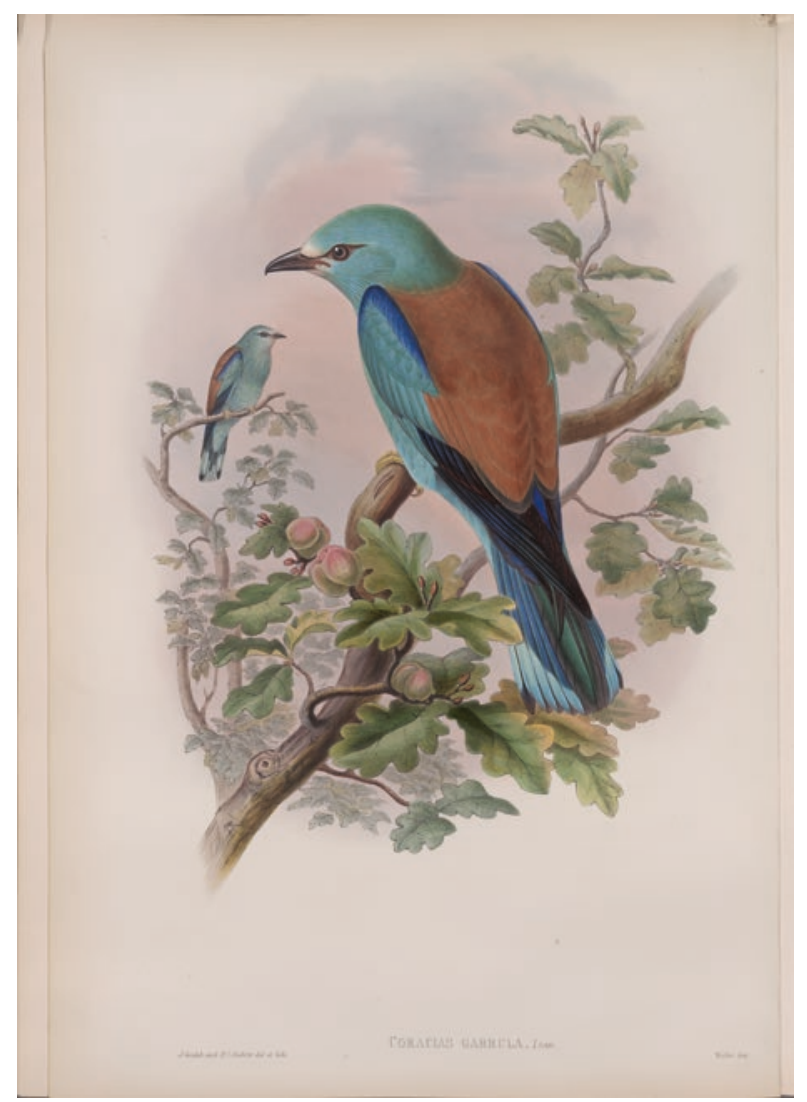

Fig. 8.3 Coracias garrula, Roller, Gould's The Birds of Great Britain, 1862-1873, hand-coloured lithograph. (@ Rare Books Division, The New York Public Library, Astor, Lenox and Tilden Foundations)

savannah or bushy plains of eastern and southern Africa. As the migratory bird can be observed both in Britain and South Africa, it caught both Barber and Gould's attention.

With its lack of sexual dimorphism (same size and weight), and its almost identical colouring, it remains a particularly fascinating species for ornithologists. ${ }^{49}$ The only difference between the sexes is that the female is slightly paler. Comparing Gould and Barber's illustrations again serves to suggest the forms of relationship which they believed were most suitable 


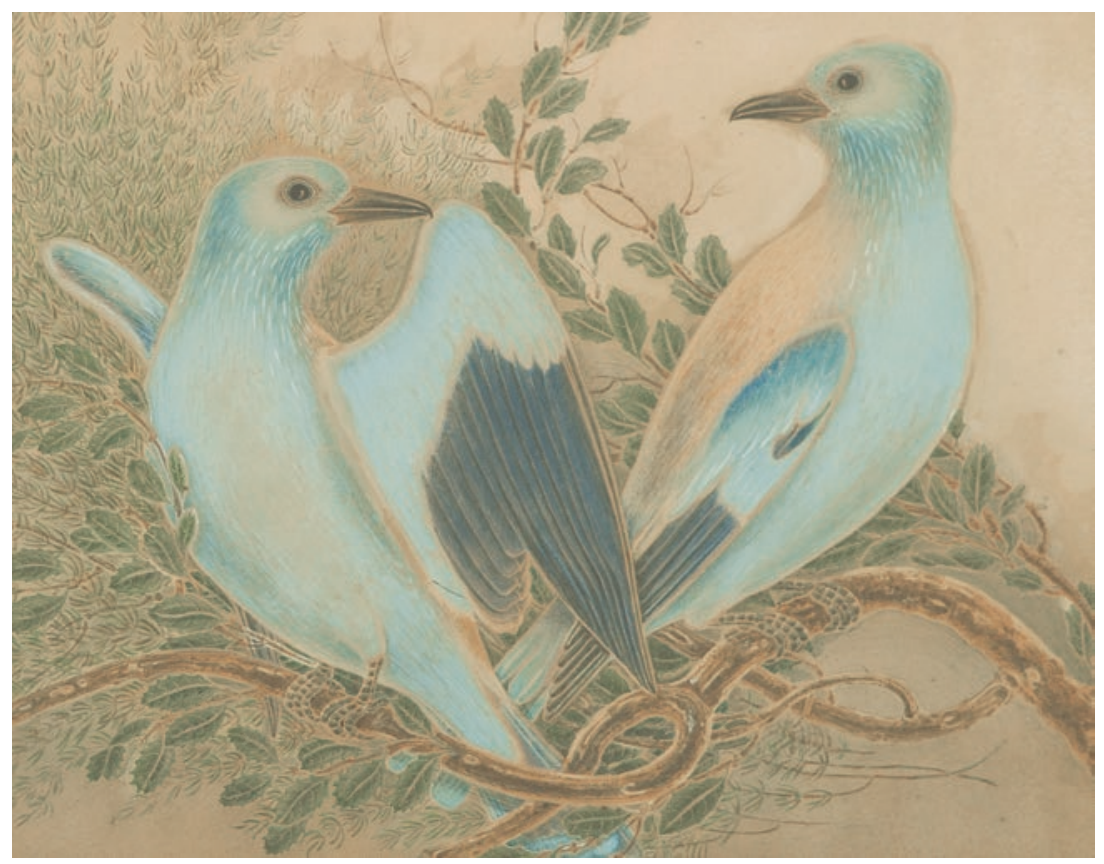

Fig. 8.4 Coracias garrula, male and female. (ㄷ) History Museum, Albany Museum Complex, Art Store no 14, photographed by Paul Greenway, P3 Photography, December 2015. All rights reserved)

for human couples. While Gould focused on the male when placing the female in the background, Barber depicted both sexes facing each other as equals, on eye level, appearing to function in harmony out of care for one another.

\section{Barber's Opinion Regarding the Institution of MARriage}

There are hardly any sources that provide insight into the married life of Mary and Frederick William Barber, but the few glimpses we can glean paint a rather bleak picture of an unhappy relationship. They may have been introduced at the wedding of Mary's younger sister to Frederick's cousin on 5 September 1842 and married just three months later, on 19 
December $1842 .{ }^{50}$ Their marriage appears to have been a pragmatic arrangement. In Frederick's sole remaining description of his wife, Mary is portrayed as a tomboy who would 'rather climb the trackless mountain "all unseen" than figure a quadrille in a heated room' and as 'a plain, simple-minded', 'slight and rather tall', 'well informed' 'girl'. ${ }^{51}$ Mary, meanwhile, did not mention her husband in any of her writings; indeed, in her travel journal, she did not even reveal that she was travelling with him on the same journey. ${ }^{52}$ In a letter written in 1847 to her sister-in-law, Barber mentioned that she had spent 'unhappy' times in her marriage, but she did not elaborate on what exactly she meant. ${ }^{53}$ She was a pragmatist who argued that humans forged their own destiny and thus attempted to always make the best out of every situation in which she found herself. ${ }^{54}$ The only surviving letter between Barber and her husband was discussed in Chap. 7. It is limited to discussing the potential expansion of the British Empire in Southern Africa and displays no personal affection towards him.

From the very beginning of their marriage, the Barbers led separate lives. They spent little time together due to the gendered nature of the division of labour on the farm. ${ }^{55}$ While Frederick would often be away on expeditions, hunting trips or in the fields farming, Barber was primarily occupied with reading, writing and working in the house. Later, while Frederick fought in the Seventh and Eighth Cape-Xhosa Wars, Barber hid with their three very young children in camps in churches or on relatives' farms. In the 1870s, Frederick was preoccupied with diamond digging and ginger ale manufacturing. By Easter 1876, twenty months after buying the ginger ale factory, their financial situation was no better than when they had arrived on the diamond fields, and the Ninth Cape-Xhosa War (1877-1878) prevented their return to Albany. When a fire destroyed their belongings in Kimberley in 1878, ${ }^{56}$ however, they were left with little choice but to leave. By this time, their marriage had become strained, and he left the Cape and her behind. ${ }^{57}$ In her travel journal, she displayed anger towards men in general, as her descriptions of some encounters during the journey reveal, ${ }^{58}$ while also making a point of repeatedly emphasising the handsomeness of their wagon-driver, Klaas-perhaps out of anger with her spouse or, in the unlikely event that he came to read her travel journal, to spite him. ${ }^{59}$

Frederick left for England to live with his older brother Alfred (1808-1884) and to turn over a new leaf in his own life. Alfred, a photographer with his own studio, lived in Totterdown, on the outskirts of Bristol. ${ }^{60} \mathrm{He}$ moved in with him, his housekeeper, Charlotte Bellinger, ${ }^{61}$ as 
well as a lodger, the widow Elizabeth Louisa Blamey (c. 1853-1926), Bellinger's niece, who was aged thirty-three at the time of Frederick's arrival. ${ }^{62}$ Frederick seems to have immediately fallen in love with Blamey, as correspondence with Alfred suggests. ${ }^{63}$ On a trip to London, he failed to bring a botanical illustration to the Royal Botanic Gardens Kew that his wife had asked him to deliver in person; this and the letter he later sent to Hooker suggest that he had other priorities at the time. ${ }^{64}$ His mind was preoccupied with the young woman he had met and fallen in love with, and his wife was far away-both geographically and emotionally.

In 1884, Alfred died and Frederick decided to stay in England. Bellinger moved to a house in Stoke View, Fishponds, further outside of Bristol, and Blamey and Frederick moved in with her. Having learned the necessary skills from Alfred, he seems to have earned a living as a photographer. $\mathrm{He}$ displayed no wish to return to Kimberley, which he proclaimed to loathe 'excessively' in his letters to a friend, and appeared neither homesick nor to have any yearning to see his family. Ambivalent about his marriage, he wrote that 'Mrs B. is seriously thinking of coming [...] this year or next'. His family had not mentioned it in correspondence, and he had already 'begun to think that the idea was given up'. He said he had 'written advising her to come at once. "Procrastination is the thief of time"' and that he wanted her 'to come now, have her spree, see all she cares about seeing'. As he did not 'want to go back yet', he made sure that she knew she could 'return home quite well without [him]'. ${ }^{65}$ It would take her nine years to visit him in England.

From 1879 to 1889 , Mary Barber led a peripatetic life. After her husband left the colony, she stayed with her brother, James Henry, in Malvern near Durban, Natal, a setting which she found to be wonderful and inspiring for naturalists as she could regularly meet with intellectuals such as the bishop John William Colenso and the botanist Katharine Saunders. ${ }^{66}$ The Anglo-Zulu War forced her to leave Natal and to return to Kimberley. She left Kimberley permanently in May 1881, just before the 'share mania'. Barber and her children split up, shared the remaining money and no longer had a common base. Her oldest son, Fred, attracted by the first ostrich feather boom (1865-1870), lived on Broxley, Junction Drift, a farm on the Fish River, Commadagga Station, Cradock line, where he reared ostriches, ${ }^{67}$ while her daughter, Mary Ellen, had moved to Cape Town. Barber and her youngest son, Hal, moved to Grahamstown before their planned trip to England. However, Mary and her sons decided to buy the ostrich farm, after which the state 
of her and her sons' finances no longer allowed for her passage. ${ }^{68}$ Barber resided at Junction Drift until 1887. ${ }^{69}$ When Broxley was sold, Barber spent time with her relatives on Table Farm, fourteen kilometres from Grahamstown, and then lived with her daughter Mary Ellen in Grahamstown. Barber accompanied Mary Ellen and her children to the goldfields of Johannesburg in September 1887, where they joined Barber's sons and son-in-law. In 1888, she sent her last surviving letter to Trimen, while also reinitiating correspondence with the recently knighted Hooker at Kew.

In May 1889, Barber and her sons travelled from Cape Town to Southampton on the Union Company's steamer Athenian for a holiday to visit Frederick in Bristol. Whether the couple had maintained correspondence and what happened to Frederick in Bristol in the meantime remains unknown. ${ }^{70}$ The entire family left Southampton for Cape Town on 4 October 1889 on board the Athenian. After their arrival in Cape Town in November 1889, the family soon scattered again. In a letter she sent to her niece Mary Layard Bowker, Barber wrote how her husband 'was boasting about his having such a lot of letters from young ladies', a statement which indicates that their relationship was more strained than ever as she had never before explicitly mentioned her husband's possible adultery. ${ }^{71}$ While Barber usually went to live with her sons in Johannesburg during summer and spent the winters with her brother James Henry at Malvern, Frederick joined his sons in Johannesburg ${ }^{72}$ and returned to Grahamstown, where he was taken ill and hospitalised before dying on 21 January 1892. He was buried the next day without the presence of his wife and children. ${ }^{73}$

The Barbers could have contemplated divorce, yet it remained effectively impracticable at the time. After the second British invasion of the Cape, Roman-Dutch law remained in force. However, from 1827 court procedures in the colony had to be held in English, while the Britishtrained lawyers and judges who were not versed in Roman-Dutch law argued and heard their cases according to English law by claiming that the two systems were equivalent. ${ }^{74}$ Whereas in Roman-Dutch law, women and men had equal rights to dissolve a marriage, the British system was 'the most rigid and harsh towards women' at the time. ${ }^{75}$ Even The Matrimonial Causes Act in Britain, which established secular divorce in 1857, allowed for a husband to obtain divorce from his wife on the simple grounds of adultery, while a woman could only seek divorce if she could prove 'adultery aggravated by desertion, cruelty, rape, sodomy, incest, or bigamy'. ${ }^{76}$ However, this act was still unhelpful to Frederick Barber, who seems to 
have longed for a law similar to recently introduced legislation in France which 'made divorce easily obtainable' if a couple had been married for twenty years and the wife was forty-five years of age or older, when both parties desired separation. This he considered to be 'an excellent law' that would certainly 'increase the amount of happiness in the world' ${ }^{77}$ Yet, in his own case, according to the remaining sources, his wife had not been adulterous, nor could Mary Barber have proven her husband's alleged adultery nor argue, had it indeed occurred, that it had been aggravated by any of the above acts. In reality, Frederick would most likely not even have been able to pay her maintenance. ${ }^{78}$ They therefore agreed to private separation, thereby also saving themselves from submitting their failed marriage to the settler community's scrutiny.

These experiences and Barber's observations on the lives of other married couples made her question the institution of marriage in general and aim to advocate to her daughter and nieces alternative vocations to that of lover, wife and mother. ${ }^{79}$ By the mid-1870s, Barber was rather outspokenly sceptical of marriage. For example, she commented wryly on a fellow ornithologist's wedding that 'the fatal knot was tied, from which there is no escape!', a comment which also stressed the virtual impossibility of divorce at the time. She firmly believed in the English satirical magazine Punch's 'Advice to people about to marry - don't' ${ }^{80}$ To her penfriend and niece by marriage, Amenia Barber, in England, she highlighted that her daughter then at the age of twenty-two was ' $[. .$.$] not engaged she might$ have been married over and over again $[\ldots]$, but she is not yet inclined to sell her liberty. I have not a high opinion of matrimony myself and I have perhaps set Highlie rather against it, which some people would think a pity, $[\ldots]^{\prime} .81$

Apart from these views which she expressed in her private correspondence, Barber voiced her concerns about marriage in a parable in which she described bird mating pairs. Here, Barber uses the relations between birds not as a metaphor but as a simile:

Many species of birds, $[\ldots]$ choose their mates once for all, and they live together (provided no accident occur to either sex) through the natural term of their lives, in such cases there is but little display on the part of the males of fine feathers, or singing to enchant the females; such birds pursue the even tenor of their way as do married people of the human race, displaying, however, great affection for each other, which is not always the case on the part of human beings. ${ }^{82}$ 
These lines were written in Kimberley, a town which she described to Trimen as 'such a dull uninteresting old place', ${ }^{83}$ at a time when her marriage was foundering. In Kimberley in the 1870s, she experienced most explicitly how white women were treated as second-class citizens. Among the 30,000 residents of Kimberley at the time, women formed a small minority. White women were particularly rare. ${ }^{84}$ These circumstances forced Barber into an entirely different role to the one she had enjoyed in Albany. She now had to entertain guests, such as eighteen-year-old Cecil John Rhodes, who had arrived in Kimberley in 1871. The hunter and explorer Frederick Courtney Selous met Barber in Kimberley in December 1879, and when he became seriously ill, Barber and her daughter carefully nursed him back to health. ${ }^{85}$ For Barber, entertaining guests was a chore, and nursing riled her in particular. ${ }^{86}$ In Kimberley, many women, who were not allowed land, labour or any means of profit of their own, became equally aware of their perilous exclusion from white men's scramble for diamonds and their mining capitalism. A prominent literary example thereof is Schreiner's eponymous character in the novel Undine, who came to the realisation that white men have money, autonomy and sexual power, while women's fate is to be dependent and subservient. ${ }^{87}$

Barber's parable illustrates how she longed for devotion and faithfulness in marriage, but was left with no option but to criticise men for making little effort to please their wives. Birds, in contrast, continued to show great affection for their mate throughout their relationship. She hereby compared birds' sexual relations with the behaviour and values of heterosexual human couples and emphasised monogamy, lifelong fidelity and harmony as typical of avian rather than human relationships. Barber saw marriage as inevitably destined to fail due to the different expectations and needs of women and men in Victorian gender ideology. This critique, in turn, highlights her view that notions of marriage did not promote gender equality, a sense of community or harmony.

Barber's aversion to marriage was reinvigorated when she witnessed how independent women turned into dependent wives and abandoned their scientific pursuits. She found it difficult to accept that the new generation of women who enjoyed more freedom of career choices than she had ever had, set different priorities for their own lives.

As Barber wrote to her niece Amenia, her daughter had been muchloved in Kimberley as 'a clever girl' who was 'perfectly fearless' and capable of doing 'almost anything' including riding 'any sort of animal no matter how wild'. ${ }^{88}$ However, as much as Barber emphasised her daughter's 
rampancy and was proud of the way in which she had raised her, the two women proved to be very different as adults. While Mary Ellen had helped her mother collect butterflies when she was younger, her scientific pursuits came to an abrupt end when she married Alexander Cumming Bailie in 1878, at the age of twenty-five. ${ }^{89}$ Mary Ellen would ultimately give birth to nine children, whose upbringing required her full attention, and Barber turned to her as a caregiver shortly before her death.

After her disappointment with her daughter's life choices, Barber held high hopes that her favourite niece, Mary Layard ${ }^{90}$ (1863-1928), the daughter of Thomas Holden Bowker, who was ten years younger than Mary Ellen, would follow in her footsteps and take up a career in natural history. She left to complete her schooling at the Huguenot Seminary in Wellington near Cape Town in 1879, at the age of sixteen, to which she later returned as a qualified teacher. ${ }^{91}$

In September 1888, shortly after the death of Mary Glanville, the curator of the Albany Museum, Barber wrote to her niece, encouraging her to apply for the new vacant post. James Henry Bowker and Barber further promised to recommend her for the position as well as to back her up. Barber also sought to convince her niece that it would 'not require a great amount of knowledge of different branches of natural history to fill such a place', 'a good general knowledge is all that is required'. Convinced that Atherstone would support the application, Barber, along with Bowker, encouraged Mary Layard not to 'underrate [her] own abilities' and pointed out that Glanville had been 'very ignorant on natural history subjects' when she arrived at the museum. ${ }^{92}$ Whether this was true or Barber only said so to encourage her niece remains unknown. It is also not known how Mary Layard reacted to this proposition or whether she indeed applied for the post. In 1889, Mary Layard received her Public Schools Certificate from the Cape of Good Hope Department of Public Education. ${ }^{93}$ A proud Barber wrote to her in November, professing how:

you are quite right in what you have done, in having left dear old sleepy Tharfield with all its natural treasures and gone forth into the world to carve out a career for yourself and as Byron says:

"better to sink beneath the shock than moulder piecemeal on the rock in sullen creek or silent Bay unseen to drop by dull decay." 94 
Besides this is the age of enterprise and energy, more than all that have gone before, every day we are hearing of both young ladies, and married women, putting their shoulders to the wheel and doing good service for themselves and families instead of being an encumbrance. ${ }^{95}$

Bowker thus joined a profession which was dominated by women, who made up almost 75 per cent of white teachers at the Cape in $1891 .^{96}$ Roland Trimen acknowledged Mary Layard in his South African Butterflies (1887-1889) for her collections of Lepidoptera and the information she provided, while she donated insects with natural history notes and land shells to the Albany Museum and the South African Museum in 1889. She also collected the type specimens of two land snail species of the same genus, which were named after her as Gulella mariae and Gulella bowkerae in $1892 .{ }^{97}$

Soon thereafter, the thirty-one-year-old married Barber's son Hal, who was then forty-four. ${ }^{98}$ In 1912, they sold their farm to buy a farm at Kiambu, close to Nairobi in Kenya. Mary Layard, meanwhile, had adopted a very different lifestyle, abandoning her scientific pursuits and her career as a teacher to focus on her household, gardening and agricultural work on the couple's coffee plantation. ${ }^{99}$ Olive Schreiner had observed similar transformations in middle- and upper-class women with marriage and their dependency on their husbands. In Women and Labour (1911), she described them as "sex parasites", economically dependent on men, taking without giving anything except their bodies in return'. ${ }^{100}$ However, Schreiner was supportive of 'a true marriage' that was 'the most holy, the most organic, the most important sacrament of life' as long as 'the woman should be absolutely and entirely monetarily INDEPENDENT OF THE MAN'. ${ }^{101}$

Barber, who had attempted to earn money through her research, illustrations and collected specimens, would have agreed with this, but had herself gone a step further in questioning the very foundations of marriage itself. Barber and Schreiner's relation to birds and how they related to their advocacy for gender equality also differed. Schreiner was equally interested in reflecting on gender equality through bird species which displayed minimal levels of sexual dimorphism or an equal division of labour between mates. ${ }^{102}$ In The Story of an African Farm (1883), Lyndall explains to Waldo that she likes ostriches as 'they share each other's work, and are companions'. An example of this behaviour is provided in her commentary of the male ostrich which broods on the eggs while the 
female forages. From ostriches, Lyndall then suddenly changes the topic to women's rights and asks: 'Do you take an interest in the position of women, Waldo?', to which she adds: 'I'm sorry you don't care for the position of women; [...] it is the only thing about which I think much or feel much'. ${ }^{103}$ With similar passion, Schreiner recalls in Woman and Labour how she saw 'cock-o-veets', ${ }^{104}$ or bokmakieries (Telophorus zeylonus), small yellow and green birds with black horizontal stripes across their necks, as a child, probably in the Karoo. ${ }^{105}$ She admires their 'inter-knit love-songs' as well as the fact that she observes them 'building their nests together, and caring for and watching over, not only their young, but each other'. This image, she discloses, 'has powerfully influenced all [she had] thought and felt on sex matter since'. ${ }^{106}$ Certain species of birds, according to Schreiner, thus attained the 'highest aesthetic, and [...] intellectual, development on earth: a point of development to which no human race as a whole has yet reached, and which represents the realization of the highest sexual ideal which haunts humanity'. ${ }^{107}$

Barber's ornithological observations, on the other hand, confirmed her preexisting ideas about gender equality. She had long been aware of the difficult position in which women found themselves in settler society. By closely observing settler and African societies for decades, Barber realised that birds, which were deemed to be on a lower rung of the evolutionary ladder than humans, were actually far more advanced in notions of gender equality-an argument that Schreiner would pick up and use, as seen above. Through her ornithological descriptions and illustrations, Barber voiced her argument for total gender equality, a philosophy so radical at the time that it was still inexpressible in concrete terms. ${ }^{108}$

\section{Barber on Birds, Platonic Friendships and Alternative Relationships to Marriage}

In her illustrations of the bird species known as Delalande's green pigeon (Vinago delalandei) as well as of the South African hoopoe (Upupa africana), ${ }^{109}$ Barber demonstrated an open-mindedness towards alternative forms of relationships. She may have depicted two further bird species which exhibit only slight degrees of sexual dimorphism. In the case of green pigeons, ornithologists regard the sexes as (nearly) identical in appearance, but in this case, Selmar Schonland, a botanist and then director of the Albany Museum, determined the illustrated birds in 1904 to be 
two males. ${ }^{110}$ The hoopoes might be a female and a male, but as they are rather pale on their lower torsos and have stripes on the back, typical characteristics of the female, it is more likely that Barber depicted two females despite their slightly different postures. ${ }^{111}$ While Barber's more obvious depictions of males and females contain nests and show the birds facing one another, these two watercolours do not. ${ }^{112}$ She might therefore have depicted a same-sex couple. ${ }^{113}$

Barber was undoubtedly interested in platonic friendships between members of the same sex. For instance, she depicted two Zulu women holding hands in a historiated initial, an enlarged letter at the beginning of a chapter of her travel journal that contains a picture (Fig. 8.5). ${ }^{114}$

Besides being a stereotypical depiction of African women with large buttocks, elongated arms and no facial features or other markings of individuality, Barber's illustration is an idealised image which portrays the amaZulu's communal harmony and is reminiscent of representations of 'noble savages'. The depiction also hints that she herself longed for this public-spiritedness, solidarity and friendship.

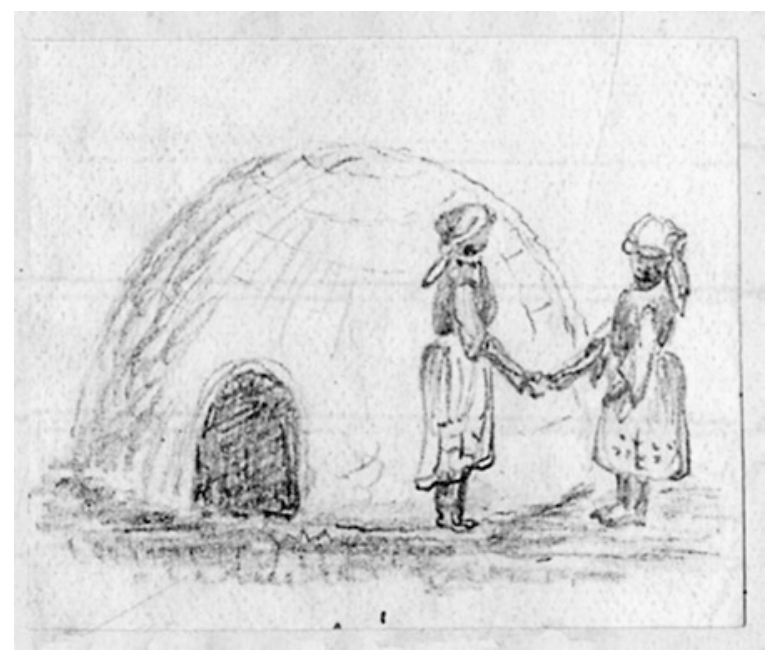

Fig. 8.5 Two Zulu women in Maritzburg (Pietermaritzburg), initiating Chapter 20, MS 10560. (C Cory Library. All rights reserved) 
The ambiguity of at least these two ornithological images offers several possible interpretations, which are not mutually exclusive and are all relevant to the question of the differences between the sexes. While Barber again emphasises the insignificance of variations between the sexes, she also presents and promotes alternative forms of sexual relationship for humans. Barber thereby challenges the heterosexual structure of bourgeois gender regimes and depicts platonic relationships to emphasise the value of friendship over that of marriage. ${ }^{115}$ Barber thus underlines comradeship and collaboration among different species of birds forming a recurring theme in her nature tales. ${ }^{116}$ This reflects her own yearning for friendship, particularly after her husband returned to England (1879).

From this stage, with her children now leading their own lives and without the financial means of a Marianne North, Barber had to rely on relatives for accommodation. However, as she did not want to be a burden to anyone, she frequently changed hosts, a lifestyle which she despised. In 1847 , she had commented on a similar period of her life after the wars when she was left with the impression that she had 'scarcely ever been a week or fortnight in one place'. Like then she must have felt that she had become 'a vagabond upon the face of the earth'. ${ }^{117}$ In this period of her life, she longed to see her penfriends, such as Trimen or her niece Amenia, to whom she was particularly close and the only ones who rivalled her brother, James Henry, for affections. This trio provided Barber with what she missed in her husband-namely, ceaseless confidence in her abilities and support for her scientific work without a corresponding demand for her to fulfil the duties which were socially expected of her as a woman, wife and mother.

By the 1880s, Barber was no longer painting ornithological illustrations or corresponding with other ornithologists about her observations. Her interest had since shifted to the protection of endangered bird species for the benefit of local agriculture in Albany. In what follows, I return to her 'Plea for Insectivorous Birds' - among other sources—and argue that, besides being an early example of activism in the field of bird conservation, this was also an attempt to argue for a 'New Woman' and increased rights for women.

\section{Advocacy for the Protection of Birds AND The Rights of Women}

Barber became a corresponding member of the South African Philosophical Society in 1878, the year of her daughter's marriage, when Barber wrote to Trimen to advocate for an opening up of science to women. She com- 
mented that she did not 'see any reason why a lady should not in a quiet way be a member of any scientific society'. ${ }^{118}$ While Alan Cohen has taken this statement at face value and seen it as an argument for women's quiet membership in scientific societies, I see it as a criticism of the contemporary ideal of the 'quiet woman'. Quietness, according to Barber, was everything but 'a blessing in a woman's character' 119 and the main reason why women's positions in society had remained unaltered for so long. With irony, she also referred to the common assumption that the 'happiness of our home', as Darwin put it in a letter to the American woman rights activist Caroline A. Kennard, would 'greatly suffer' if women were educated. ${ }^{120}$ Barber used the example of the Scottish mathematician and astronomer Mary Fairfax Somerville (1780-1872) to show her men colleagues what women could achieve in both science and society. Somerville, the first woman member of the Royal Astronomical Society, had reconciled family life with her career as a scientist. She had had two sons in her first marriage and four more children in her second. Her first husband, Captain Samuel Greig, whom she married in 1804, neither hindered nor supported her in her scientific endeavours as he deemed women intellectually inferior to men. ${ }^{121}$ After his death, the inheritance gave Somerville the means to participate in the scientific community of mathematicians and publish her own work - for which she won the mathematical repository's medal - under a pseudonym. Initially, mathematics was a way for her to understand the workings of God, but her work led her far away from those of leading mathematicians. Her second husband, the navy physician Dr. William Somerville, ${ }^{122}$ was very supportive of her scientific pursuits. ${ }^{123} \mathrm{Her}$ paper on 'The Magnetic Properties of the Violet Rays of the Sol or Spectrum', which was presented to the Royal Society in 1826, as well as her volumes on The Mechanism of the Heavens and On the Connection of the Physical Sciences, which were published in 1831 and 1834, respectively, saw her become one of the foremost scientific writers of her day. ${ }^{124}$ Barber argued that Somerville's virtues as 'a good wife, and a kind mother' exceeded even 'her scientific abilities'. ${ }^{125}$ Barber thereby underlined that middle-class and upper middle-class women could accomplish the domestic duties which men expected of them while still fulfilling their intellectual vocation, and should thus be allowed to become equal members of scientific societies.

Barber may have also admired Somerville for her activism on issues of women's education. Somerville, who was convinced that women had the intellectual capacity to assume a much higher place in society than that 
which was currently assigned to them, ${ }^{126}$ was also the lead signatory on John Stuart Mill's petition for women's franchise and was a member of the General Committee for Women's Suffrage in London. These endeavours, as well as her firm belief in white supremacy, ${ }^{127}$ made Somerville the ideal role model for Barber.

Barber hoped that the next generation of white women in the Cape would be able to hold similarly high positions in science and society. To achieve this, Barber felt, she had to raise awareness for the need of a 'new woman'. In 1886, Barber subtly criticised the Victorian ideal of womanhood in her paper on 'A Plea for Insectivorous Birds'. Six years earlier, the Anglo-Australian writer and illustrator Louisa Anne Meredith (née Twamley, 1812-1895) had published Tasmanian Friends and Foes (1880), in which she, as an early member of the Society for the Prevention of Cruelty to Animals, lobbied against the plume trade. She blamed, through a man character, 'vain, idle women' who did not realise that 'our ideal of the sex, would be too humane and gentle to endure the thought that a single sparrow should be destroyed for their pleasure'. ${ }^{128}$ The quote suggests that according to men's ideal of women, women would not be capable of killing birds due to their moral superiority. With this sentence, Meredith both criticised women's behaviour and the image of women held by men which was seen as responsible for women's behaviour in the first place. Barber, however, disapproved of women who were only concerned with pleasing their husbands, did not manage to scold their sons for killing birds and were unaware of what was going on outside the domestic sphere. Barber described matter-of-factly how birds in full plumage were shot in the middle of the breeding season to supply the plume trade. The consequences, she argued, were the perishing of offspring, while mates would die 'of grief' as non-gregarious birds lived in pairs and were 'most affectionate and kind to each other'. ${ }^{129}$ Furthermore, every bird which was killed, Barber claimed, allowed the survival of 'tens of thousands' of insects, which resulted in locust swarms and the corresponding deterioration of the environment. Unlike the curator of the Albany Museum Mary Glanville (Chap. 4), who had blamed only the hunters who shot birds for women's fashion, Barber held women responsible:

[...] I could enumerate many ladies of high character and standing, with warm generous, and true hearts, who would shrink from allowing their children to do a deed of cruelty, even to the destruction of a fly, nevertheless, 
thoughtlessly and inadvertently, they will wear in their hats that ghastly emblem of death, a stuffed bird! ${ }^{30}$

Barber's condemnation of the plume trade was, thus, also a criticism of women who followed the Victorian gender ideology and felt they had to please men with their beauty. She thus blamed both men and women, producers and wearers, for the plume trade and contemporary gender ideology.

After its publication, the paper circulated as a pamphlet, and the colony's Educational Department was asked by the Natural History Society to prepare 'an illustrated sheet for the use of schools, with a description of our useful birds, giving such information respecting our insectivorous birds in general'. ${ }^{131}$ Barber's ideas on the protection of birds as well as knowledge of her advocacy for women's rights thus circulated among settlers in Albany. As birds provided a vehicle through which she could urge for women's rights, Barber referred to them as her 'companions' or 'best friends'. ${ }^{132}$

The emancipatory component of the transnational campaign against the plume trade has hitherto been neglected in the scholarly debate. In February 1886, a few months before the publication of Barber's paper, the American conservationist and editor of the magazine Forest and Stream, George Bird Grinnell, had announced the foundation of the Audubon Society. This society urged the public to oppose the killing of birds for the millinery trade and appealed to women to serve as leaders in this fight. ${ }^{133}$ The American ecofeminist and historian of science Carolyn Merchant has argued that American women who responded to this call, such as the ornithologist Florence Augusta Merriam Bailey, were 'predominantly conservative in their desire to uphold traditional values and middle-class life styles' and drew on 'a trilogy of slogans - conservation of womanhood, the home, and the child'. ${ }^{134}$

It is true that there are conventionally gendered notions in her work, but Bailey herself appears to have employed such stereotypes only in order to dismantle them. For example, she wrote how 'the timid female' was not very different from the 'lordly male' as, after being 'painfully shy' for a while, 'she was actually making a pass at a usurper'. ${ }^{135}$ Bailey argued further how, 'Like other ladies, the little feathered birds have to bear their husbands' names, however inappropriate'. She found that an 'injustice' as an 'innocent creature with an olive-green back and yellowish breast' was always called 'the black-throated blue warbler, just because that happens 
to describe the dress of her spouse!'136 These two exemplary statements suggest that it is well worth reevaluating the movement in the US to ascertain whether there were similar attempts such as those of Barber's advocacy for women's rights through the writing of pleas for the protection of birds.

The bird protection movement paralleled the emergence of the women's rights movement. However, according to the English schoolteacher and governess Beatrice Hicks, who lived in the Eastern Cape from 1894 to 1897 , the latter had yet to develop at the Cape. In The Cape as I Found It (1900), she rather exaggeratedly reported to her readers that while the women's rights movement had triumphed in England, it was only at its very beginning at the Cape. ${ }^{137}$ She went on to compare the purportedly miserable situation in which women at the Cape found themselves with the comfortable social position enjoyed by British women. ${ }^{138}$

In the late nineteenth century, amid the changes wrought by early Cape industrial capitalism on the diamond and gold fields, a suffrage movement had developed out of a wider social transformation which had also occasioned a redefinition of gender roles. Its leaders were middle-class, urban, Anglophone women who followed the example of metropolitan, especially British, suffragists. ${ }^{139}$ British suffrage efforts date back to 7 June 1866, when John Stuart Mill and Henry Fawcett had presented a petition to the House of Commons for an extension of the franchise to all householders. This was drafted and signed by 1499 women, including many prominent figures, such as Mary Somerville, Florence Nightingale and Harriet Martineau. In 1867, the first women's suffrage societies were founded in London, Edinburgh and Manchester, where Lydia Becker initiated the Society for the Promotion of Women's Suffrage. ${ }^{140}$ In 1869 , Mill published The Subjection of Women, which became the bible of the women's suffrage movement. Although legislation such as the Custody of Infants Act (1873) or the Second Married Women's Property Act (1882) enhanced the situation of women in Britain by granting them the right to maintain custody of their children after divorce and to keep their property separate from that of their husband, suffrage remained the ultimate goal for the movement. ${ }^{141}$ Limited success was achieved in this regard, with a woman's suffrage bill introduced every year throughout the 1870s (with the exception of 1875), ${ }^{142}$ and the introduction in 1870 of a municipal franchise for women to vote in local elections. ${ }^{143}$

At the Cape, the candid criticism of the subordinate status of women in Schreiner's The Story of an African Farm caused controversy and deeply 
impacted upon the suffrage movement both locally and abroad. In 1886, sixty years after its foundation, the South African College in Cape Town opened its chemistry classes for women on a trial basis for a period of one year before becoming the first university college at the Cape to fully accept women students the following year. In 1892, seven years before Barber's death, a motion for granting the franchise to white upper-class women was defeated in the Cape House of Assembly. The proposed legislation had blurred notions of whiteness, civilisation and property to argue for women's suffrage. ${ }^{144}$

Barber's arguments differed from those of her English suffragist contemporaries in that she did not acknowledge any gender differences. Suffragists had generally argued that, while women and men should be treated equally, there were also clear differences between the sexes. It was precisely the varying interests arising from these differences, they argued, which required adequate representation through the advent of the franchise for women. ${ }^{145}$ Furthermore, both proponents and opponents of women's enfranchisement agreed that women were morally superior but physically weaker beings, who paradoxically derived their virtue from their very weakness. As such, the virtue of women in the domestic sphere was presented by suffragists as the civilising antidote to the vice of men in the public sphere. ${ }^{146}$ Barber, on the other hand, was convinced that women shared identical abilities with men and could achieve whatever men had hitherto accomplished. ${ }^{147}$

In contextualising Barber's arguments within contemporary debates about gender equality, I did not mean to imply that the idea of women's rights was developed in the metropole and subsequently imported to the global South. Bill Schwarz has shown how systems of thought around notions of 'racial whiteness', 'white men's countries' and the conviction that white men were destined to reign over humanity were forged in settler colonies, such as Australia, New Zealand, South Africa and Rhodesia, before being introduced to Britain and the rest of the world. ${ }^{148}$ White gender relations, which were negotiated through ornithological work on birds from the South, in white settler colonies such as Australia and the Cape Colony-as Barber and Gould's case shows-were brought back to Britain and the rest of the world through publications, which concurs with Schwarz's argument that a peculiar white masculinity was shaped in settler colonies of the South and then introduced to Britain, and not vice versa. ${ }^{149}$ In addition, the developing women's rights movement was likewise a parallel undertaking in numerous parts of the world which overlapped with 
other campaigns, such as that for the protection of birds. Actors throughout the world and across these various movements influenced one another. Schreiner, for instance, undoubtedly had an impact on the women's rights movement outside South Africa.

Virginia Woolf followed in Barber's footsteps with her feminist article on 'The Plumage Bill' (1920). Woolf did not actually refer to Barber but seemingly drew on her. Woolf's meticulous research on her feminist predecessors for her lectures at Girton College and Newnham College, Cambridge, which eventually resulted in A Room of One's Own (1929), shows that she knew about many previous women scholars, scientists and writers. She had been aware of women ornithologists fighting against the plume trade and advocating for women's rights at the end of the nineteenth century. Woolf argued here-much more explicitly than Barberthat it was wrong to blame women for the plumage trade as they were also its victims, rather than its agents. She claimed that if women contributed to the suffering of birds, it was only through their ignorance and dependency on men, rather than due to hard-heartedness or a greedy taste for luxury. Sexist society made them act as they did by condemning women's pleasures as sinful, while valorising men's lust for women, hunting trophies and money. In the case of the plumage trade, men were particularly to blame as they hunted birds, sold feathers and, as members of parliament, failed to support the proposed legislation to prevent these very acts. Woolf's attempt to follow two agendas in one article was seemingly misunderstood. While she was criticised for writing more about 'injustice to women than about the suffering of birds', ${ }^{150}$ Barber's subtler advocacy for women and birds had been equally misinterpreted, attracted much less attention and was quickly forgotten.

\section{Barber and the Rights of African Women}

Whether Barber advocated for the rights of African women is a challenging question. It is clear that Barber observed gender relations among groups of Africans whom she encountered, noting examples of egalitarian relationships between the sexes, or women who displayed characteristics that were traditionally gendered as men's in Britain and settler society. For instance, she described with humour how at Durban Bay, she frequently saw what were probably Zulu women "“paddling their own Canoes", quite independent of the lordlier sex' ${ }^{151}$ On another occasion, Barber described how the San living in the Kalahari collected food together. She idealised their cross- 
gender communality and shared labour practices, possibly out of longing for more egalitarian relationships between the sexes in her own society. ${ }^{152}$

Barber's contemporaries were similarly inspired by what they observed among Africans. The 'stridently imperialistic'153 writer and political commentator Harriet Ward (1803-c.1865), for example, wrote in the first Southern African colonial novel-the first English novel set entirely at the Cape-Jasper Lyle (1851) that as soon as 'a Kaffir woman' 'taste[d] her freedom', 'she is like a bird on the wing again'. ${ }^{154}$ Ward wished that settler women could also be as free as birds and longed them to follow the example set by Xhosa women. Barber, who had probably come across Ward's writings, shared this view.

How much Barber knew about Xhosa, Mfengu and San gender relations is difficult to determine. Yet, as it seems that she had more admiration for the nature of the relationships between African couples than for those between European husbands and wives, she appears to, at least in this regard, have prioritised the fight for gender equality above the need to present an unfailing belief in the supremacy of all aspects of white culture.

Nevertheless, as much as European women at the Cape were concerned about demanding rights for themselves, they trained African women forand thereby forced them into-domestic roles. As Xhosa women were often employed in domestic service, the relationship between white and black women was characterised by both physical proximity and social distance. According to the sociologist Jacklyn Cock, the 'external inequality' inherent in this relationship 'blocked any recognition of a common womanhood on the part of the employers' ${ }^{155}$ In missionary institutions, African women were likewise socialised into domestic roles typical of Western women. Although many women teachers and missionaries challenged some aspects of the limited role assigned to women in Western societies, they did not question the education of black girls as domestic servants in their own schools. ${ }^{156}$

The Scottish doctor and teacher Jane Elizabeth Waterston, for instance, educated African girls and women within circumscribed gendered spheres while working as Superintendent of the Girl's Institution at Lovedale Seminary, near Alice, British Kaffraria from 1867 to 1873 . She had been one of the first women to study medicine and gain a medical degree in Britain, ran a medical department at Lovedale from 1880 to 1883, and worked as a physician in a private practice in Cape Town, where she educated midwives and established a Ladies Branch of the Free Dispensary. Waterston, the first woman doctor at the Cape, ${ }^{157}$ thus succeeded in rais- 
ing her own status in society, but was not concerned with changing that of other women. ${ }^{158}$ What she was doing instead was working from the inside to ameliorate their situation and physical wellbeing.

The British feminist Vron Ware has shown in her case studies how ideologies of racism and feminism overlapped. She has demonstrated how white women had to construct black women as in need of salvation by white women. These white women thereby legitimised their racist and imperialist actions, in order to create themselves as 'guardians of civilisation' and empower themselves. ${ }^{159}$ Ware analysed a similar case to that of Waterston when she focused on how Annette Ackroyd (1842-1929) who travelled to Calcutta when she was twenty-nine to start a school for Hindu girls. Ackroyd hoped to change gender ideology but found herself trapped in her imperialist attitudes due to which she could not adapt to Indian women's lifestyles. Ackroyd and others believed that British women had a civilising role to play in uplifting Indian women subordinated by a backwards culture.

Although Barber did not engage with the Woman Question publicly, she did so privately and on a theoretical level. Unlike proponents of the women's rights movement in Britain, Barber did not focus on differences between the sexes-whether in terms of body, mind or character-but underlined the commonalities shared by men and women which, she believed, should give rise to gender equality. Barber referred to differences either to dismiss the idea of gender characteristics or to ironically argue for these characteristics being both part of male and female species.

A close reading of her writings, however, has shown that those whom she had in mind when she wrote about 'women' were primarily those from her immediate social network of British settler women. ${ }^{160}$ Furthermore, her scientific feminism was inextricably interlinked with the racist discourse of her science. As a member of the 'superior race' and 'weaker sex', she felt privileged and enabled to change white women's situation in science and society. ${ }^{161}$ Barber drew from her observations of Africans and occasionally acknowledged African influences in her scientific writings. Nevertheless, the progressive views on conservation and gender equality which she partly derived from these influences were still fused within overtly racist paradigms of thought.

Barber marginalised herself with constructing avifauna as a sphere of gender equality. The two aims she followed in her ornithological researchto make birds better known and to advocate for gender equality — contributed to her marginalisation as an ornithologist, as she was received as a 
collector and informant by Layard not as an equal colleague. Not openly voicing her concerns about the Woman Question, she marginalised herself from the women rights movement which did not see her as a pioneer. Given that women who did not fulfil the cult of domesticity were treated as having a mental disorder, that a woman without a husband was seen as a pathological case suffering from a personality disorder and that women were seen as living in an anachronistic space, 500 years behind the man, ${ }^{162}$ Barber's ornithological feminism is remarkable. Barber's 'Plea for Insectivorous Birds' was her last publication as a naturalist before her death. ${ }^{163}$

Towards the end of Barber's life, women at the Cape increasingly began to organise and empower themselves. European, and particularly British, immigrants introduced the ideas of social movements such as the women's rights movement to Cape intellectuals. Yet, these few radical thinkers found themselves in an environment which was very hostile to further female emancipation. The Women's Christian Temperance Union, founded in 1889, was the first organisation to fight for women's suffrage at the Cape. Afterwards, the South African Labour Party was for many years the only party in the South African Parliament to include women's suffrage as part of their programme. These first advocates for women's enfranchisement, like in Britain, were middle-class Christians who believed in women's moral superiority. At best, these white women addressed the situation of black women from 'the perspective of charity, not sisterly solidarity'. ${ }^{164}$

Unlike Barber, the suffragists in the 1910s and 1920s did not challenge that women had nurturing capabilities, greater moral purity and were therefore responsible for domestic duties as wives and mothers. Instead, it was argued that due to these characteristics women had a special contribution to make to politics and that their enfranchisement would therefore lead to the general good. ${ }^{165}$ After 1923, the issue of race determined the debate and was where the political interests lay. ${ }^{166}$

After women gained the vote in Britain in 1918, and the vote on the same terms as men as a result of the Representation of the People Acts 1928, the racially exclusive Act of Parliament on 19 May 1930 enfranchised white women over the age of eighteen in South Africa. There was no common sisterhood or sense of community among women who were separated due to linguistic and ethnic boundaries as well as race consciousness. ${ }^{167}$ The interests of white women who had already been privileged were advanced. ${ }^{168}$ White women in South Africa and Rhodesia wanted 
gender equality but not racial equality as they were satisfied with their position as part of the 'superior race'.

Prior to women's enfranchisement, the Plumage Act was eventually adopted in 1921 and prohibited the sale, hire and exchange of the plumage and skins of certain wild birds. The abolition of the trade had much to do with humanitarian ideals as well as with changing mores in the everyday lives of women. These deemed the wearing of oversized, constraining hats as outmoded and favoured new hairstyles such as the bob and other shorter cuts which suited different kinds of hats. ${ }^{169}$ This new fashion had much to do with the ideal of the 'New Woman'.

An analysis of the micro-politics of Barber's knowledge production should not stop with Barber's death; the collections which she left behind in museums, herbaria and archives require continued critical examination, both in terms of how their uses have changed over time, what their impact on historiography has been and will continue to be. Chapter 9, thus, connects the themes examined in Parts I, II and III and sets the scene for the conclusion. It explores what has become of selected collections since Barber's death and what the potentials, benefits and dangers of current archival practices are.

\section{Notes}

1. (Jacobs 2016, 6-7).

2. (Lévi-Strauss 1966, 204); (Galaty 1998, 229).

3. (Wollstonecraft 1833,58 ).

4. Quoted in (McClintock 1995, 286). In Darwinism and Politics (1890), the British philosopher David G. Ritchie criticised anti-feminist statements in regards to locking up women like birds in narrow cages and then blaming them for being 'incapable of flying'(Ritchie 1909, 68-69).

5. On 7 January 1836, during his inaugural speech as governor of the Province of Queen Adelaide, Sir Harry Smith, for instance, emphasised to the gathered Xhosa chiefs that-unlike commonly practised in Xhosa culture-agriculture was a man's duty, while women should occupy themselves with sewing, repairing and washing men's clothes as well as cooking their food, milking livestock and keeping house and children clean (Cohen 2011, 25).

6. Reversed Proverbs, No. IV, in (Barber 1898, 87).

7. Potter was also a scientific illustrator and naturalist, contributing to research on English and Scottish fungi, lichens, fossils and insects. See for example (Lear 2007, 76, 77, 85, 98, 127). 
8. (Levine 2006, 197); See for example (Harley 2014).

9. (Hamlin 2014, 6).

10. As can be seen, for instance, in the anthropomorphic ink sketch of the stone grasshopper found in Grahamstown, notable for its anthropomorphic friendly face, RES, Trimen Correspondence, Box 17, Letter 62/2, Highlands, 2 November 1868.

11. "A Plea for Insectivorous Birds: A Paper by Mrs. F. Barber", HM, SM $5501(46), 12$.

12. Becker won a gold medal in the Kensington Society's national competition in 1862 for her collection of dried plants. This encouraged her to share her botanical knowledge in writing (L. E. Becker 1864). Becker also wrote 'a book on elementary astronomy [sometimes referred to as Star Gazing for Novices], which did not get into print' (Kent 1987, 186); (Parker 2001, 630). For biographical information on Becker, see (Kelly 1992); (Blackburn 1902, 23-43, 180-188).

13. See for example (Wallace 1904; Le-May Sheffield 2001, 139-194).

14. (McClintock 1995; Stoler 2002; Ware 2015).

15. See for example (Bean and van Heyningen 1983); (Walker 1990); (van Heyningen 1996); (Bank 2016). This tendency can be observed not only in South Africa.

16. Anthropologist Winifred Tucker Hoernlé (1885-1960), for instance, voiced her concerns in speeches. Women scholars often were active champions of women's rights in lives and works, with a deep belief in gender equality. Andrew Bank has described the pioneering anthropologists not only as humanists with their universalism and deep understanding and respect for African societies but as feminists in their establishment of gender studies long before African history became a discipline. More explicitly feminist was the social anthropologist and scholar-activist Iona Simon Mayer (1923-), see (Bank 2019).

17. Barber to Thomas Holden Bowker, Highlands, 16 June 1862, HM, SM $5325(9)$.

18. Smith in (Shteir and Lightman 2006, 93).

19. Selmar Schonland listed seventeen of her ornithological paintings. (Schonland 1904, 101-102); At least two, including one of a pair of hoopoes (number 13), have been used to illustrate a set of notelets sold in the museum as souvenirs. The hoopoes are also on the cover of Kronos 41 (2015).

20. As one of his main sources of information, many passages from Barber's letters, which constitute the only evidence of their collaboration and are closely analysed in this chapter, were quoted in (Layard 1867). Unfortunately, none of Barber's stuffed birds could be traced in the Iziko Museums of South Africa collection or at the Albany Museum. 
21. See for example (Mitchell 1986, 1994, 5, 95); RES, Trimen Correspondence, Box 18, Letter 109, Kimberley, 27 November 1878.

22. The iconography of birds could be discussed much more broadly within the British Empire and beyond. I could also have taken research on other non-human animals such as bees and monkeys into account, but decided to limit myself to the case study at hand. See for example (Daston and Mitman 2006); (Kosek 2010); (Mavhunga 2011); Also see (Raffles 2001, 2013).

23. See (Foucault 1984, 2006, 317-329); http://foucault.info/doc/documents/heterotopia/foucault-heterotopia-en-html, date accessed 3 November 2016; Foucault's concept of 'heterotopia' has recently attracted increasing attention, see for example (Kupper 2012).

24. (Barber 1878, 34-35).

25. (Barber 1878, 30).

26. (Bowdler Sharpe 1884, 582).

27. Feminist author Virginia Woolf wrote about it in a 1942 article. (Woolf 1966).

28. (Stoler 1991, 82).

29. (Vicinus 1977, $\mathrm{x}$ ).

30. M. E. Barber to Mrs. Holden Bowker, 13 May [1854?], HM, SM $5325(2)$.

31. See (Paxton 1991, 23); Romanes, July 1887, quoted in (Hamlin 2014, $71)$.

32. See for example (Endersby 2009).

33. (Layard 1867, 226); (Bowdler Sharpe 1884, 128).

34. (Hausen 1976).

35. (Layard 1867, 105); (Bowdler Sharpe 1884, 204).

36. M. E. Barber to Amenia Barber in England, Highlands, 16 November 1868, Late Gareth Mitford-Barberton's Private Family Archive, Serial No 015 .

37. Mary E. Barber to E. L. Layard, 22 June 1865, quoted in (Layard 1867, 240-241).

38. See (Schonland 1904, 101-102).

39. (Layard 1867, 105).

40. (Smith 2001, 58).

41. See (Smith 2007).

42. See for example (Smith 2001, 2006a, b).

43. See (Chisholm 1944).

44. A recent biographical novel allows insights into the long-overlooked Elizabeth Gould's life and work: (Ashley 2016).

45. (Smith 2006b, 88-89). For feminist critiques on the subject, see, for example, (Beer 2000, Chapter 7); (Jann 1994); (Richards 1983); (Russett 1989); (Yeazell 1991).

46. (Smith 2006b, 89). 
47. Quoted in (Smith 2006a, 100, 103).

48. (Sinclair and Davidson 2006, 206).

49. (Fry and Fry 1999, 100-101, 298-300). They have been 'near threatened' since 2005: http://www.birdlife.org/datazone/species/factsheet $/ 22682860$, date accessed 8 August 2015.

50. They may also have encountered one another at one of the frequent afternoon picnics or evening dances that were organised for eligible singles in Albany. See, for example, Diary of Sophia Beddoe 1862-1864, CL: PR 7182. However, most texts date their wedding to some three years later, in 1845. Most biographical notes, see for example (Gutsche 1972); (Gunn and Codd 1981, 87-88); (Beinart 1998, 793), follow MitfordBarberton's erroneous date of 1845: (I. Mitford-Barberton 1934, 71). Botanists White and Sloane dated their wedding to 1840: (White and Sloane 1937, 100). Yet, the actual entry in the marriage register of St George's Church, Grahamstown, and the marriage notice in the Graham's Town Journal confirm it had taken place in 1842. Marriage register of St George's Church, CL (MS 14879/2); marriage notice in Graham's Town Journal, 22 December 1842. David Hilton-Barber, a great-great grandson of Hugh Atherstone Barber, Frederick's brother, argues that their courtship had been an 'on-and-off affair' for a period of five years. His description is one-sided, arguing that Mary Elizabeth must have been attracted to her future husband, as he was a good match: cultured, educated, handsome, healthy, only five years older than her, interested in science, well-connected in settler society, related to the Atherstones and had a regular income. Hilton-Barber believes that the Bowkers had given up hope that Mary would marry, as she was already twenty-seven by the time Frederick proposed (1845) (Hilton-Barber 2014, 52). Family rumour has it that he then requested that Mary join him on the farm Bloemhof near Graaff-Reinet, where he was very busy in his job as an overseer, and that the wedding should take place there. To this proposition, Mary's indignant mother is said to have replied that if he did not deem her worthy of fetching himself, Frederick could forget about any possible union (I. Mitford-Barberton 1934, 72); (Hilton-Barber 2014, 52 ). Given that they married in Grahamstown, he did what his motherin-law expected him to do.

51. F.W. Barber to Rev. Henry Barber, Near Glen Avon, Somerset, 3 March 1844, HM, SMD 739.

52. See (Hammel 2016, especially 123-125).

53. M. E. Barber to Mary Anne Bowker, 15 November 1847, HM, SM $5325(18)$.

54. RES, Trimen Correspondence, Box 17, Letter 36, Highlands, 22 March 1864.

55. (Cohen 2011, 26, 37). Initially, Mary joined her husband on the Bloemhof farm, where-besides his role as farm overseer-they sup- 
ported the Powell family after the sudden death of the farm owner's wife. Barber might have looked after the four young children who had just lost their mother.

56. RES, Trimen Correspondence, Box 18, Letter 107, Kimberley, 17 August 1878.

57. Julia Eliza Bowker to her daughter Mary Layard Bowker at the Huguenot Seminary, Wellington, 4 January 1879, Late Gareth Mitford-Barberton's Private Family Archive.

58. See, for example, 'all men are liars', RES, Trimen Correspondence, Box 18, Letter 107, Kimberley, 17 August 1878; (Barber 1962, 45, 50, 63, 64).

59. As discussed in Chap. 3.

60. The Bristol Record Office stores a number of photographs which Alfred took in his studio (Ref. no. 41990/P/21-25).

61. (Cohen 2015, [page 6]).

62. (Cohen 2015, $[6,8])$.

63. He soon left his brother for a three-to-four-month trip to see old family sites and visit relatives. While travelling, he frequently corresponded with Alfred and always enquired about Blamey's welfare and seems to have anonymously sent her a gift. F. W. Barber to Alfred Barber, Leek, 14 June; Leek, 22 June; 39 Bath Street, Leek, 25 June; 39 Bath Street, Leek, 27 June and 18 Bridge Terrace, Harrow Road, 29 June 1879, Late Gareth Mitford-Barberton's Private Family Archive. (Cohen 2011, 4).

64. F. W. Barber to J. D. Hooker, Cisco Villa, Totterdown, Bristol, 23 December 1879, KLAA, Director's Correspondence, Vol. 189, Letter 100 .

65. F. W. Barber to George Hull, quoted in (Cohen 2011, 5). Underlined (here italics) in original.

66. See (Guy 1983, 1997, 2001); (Creese and Creese 2010); (Bayer 1979); (Gunn and Codd 1981; Glen and Germishuizen 2010).

67. After concerned nature conservationists started lobbying against millinery and the wearing of bird feathers obtained from threatened species in the colonies, ostrich feathers became a popular alternative as ostriches did not have to be killed in order to acquire their feathers, with the trade soon becoming a lucrative branch of the Cape Colonial economy. See for example (Stein 2010).

68. RES, Trimen Correspondence, Box 18, Letter 112, Grahamstown, 11 August 1881.

69. See for example (Cohen 2000). Her sons followed the gold rush to the Witwatersrand and what later became known as the town of Barberton, 360 kilometres east of Johannesburg. Barberton was named after Barber's nephew Graham Hoare Barber (1835-1888) who informed the state sec- 
retary that he and his two cousins Fred and Harry, Mary Elizabeth Barber's sons, had discovered gold where the Umvoti Creek entered the De Kaap valley. The magistrate of Lydenburg was asked to investigate the matter and named the township Barberton on 24 July 1884 . Harry later commemorated the discovery in his applied surname Barberton that he later hyphenated to Mitford-Barberton. See (Hilton-Barber 2014, 81-88).

70. She took this opportunity to call on Marianne North at Mount House in nearby Alderley, Gloucestershire. Barber and her sons had also planned to travel extensively in England and Europe to visit their scientific friends, but she had difficulties finding her way in large urban areas to which, having hitherto spent her life almost exclusively in the remote countryside, she was yet to grow accustomed. Her brother James Henry wrote to Trimen that he had 'to send her some addresses of people in London and although she is there herself she cannot find them it seems awfully stupid of her'. Nevertheless, she was able to fulfil a dream by paying several visits to the Royal Botanic Gardens Kew, although she missed meeting its director William Turner Thiselton-Dyer on each occasion. She seems to have left her address book at the Cape, did not know the address by heart and might not have been able to make an appointment; or found it unnecessary to do so in the conviction that the director would always be in his office. RES, Trimen Correspondence, Box 21, Letter 366, the Durban Club, 24 July 1889.

71. M. E. Barber to M. L. Bowker, Woods Hotel, 28 November 1889, Late Gareth Mitford-Barberton's Private Family Archive.

72. There they were unsuccessful and left deeply in debt and borrowed money from their cousin Hilton Barber and uncle James Henry Bowker to rebuild their lives. (Cohen 2015, n.p. [page 15 out of 20]).

73. According to Dictionary of South African Biography, his date of death was 2 January, but his tombstone reads 21 January, as does his death notice, which was filed on 19 March 1892 and signed by Edwin Atherstone. See (Cohen 2011, 91); (Mathie 1998, 2:215).

74. Beat Lenel, "The History of South African Law and its Roman-Dutch Roots" (2002), 5,

http://www.lenel.ch/docs/history-of-sa-law-en.pdf, date accessed 8 March 2016.

75. Justice Cloete quoted in (McKenzie 1997, 221).

76. (Christensen Nelson 2004, xxi-xxii); (Kitchin 1912, 184).

77. F. W. Barber to George Hull, quoted in (Cohen 2011, 5). Underlined (here italics) in original.

78. Frederick first obtained a lucrative job as an overseer, superintending Khoekhoe and Mfengu shepherds who were looking after flocks of 4000 
to 5000 sheep. This was a lucrative job at the time (see advertisement in the Grabam's Town Journal for a similar position on another farm suggests: Graham's Town Journal, 2 March 1842). He then struggled to make a living as an independent farmer. In 1844, he confidently predicted in a letter to his brother, a parson in the US, that through owning 4000 sheep and by growing their own vegetables, his family would be able to live comfortably (Cohen 2011, 38). The Seventh Cape-Xhosa War interrupted this plan, however, as the family lost many of their cattle and sheep and had twice been 'reduced to the verge of ruin' (KLAA, Director's Correspondence, Vol. 59, Letter 8, W.G. Atherstone to W. J. Hooker, 9 March 1849). Frederick also supported his brother Hugh, who had followed him to the Cape in 1840 and continued to represent a considerable burden on the family income. See (Cohen 2011, 29). Sometime between 1848 and 1850, they bought the Highlands farm. Once the Eighth CapeXhosa War was over, Highlands was leased and the family moved again, first to Mary's brother Octavius' farm in the mountains near GraaffReinet. In recognition of Frederick Barber's services with the Burgher Forces which fought against Chief Sarili ka Hintsa (1810-1892) in the Eighth Cape-Xhosa War, he was then given the Lammermoor farm on the Zwart Kei River near Queenstown, where the Barbers lived from 1854 to 1858 . However, the Barbers were also unhappy there, as the area was too mountainous for sheep farming and equally unsuitable for crop and cattle farming. The family rented out the farm and returned to their beloved Highlands. Their descendants conceal the economic reason by explaining that the locality was 'detrimental' to Barber's health, as she had been suffering from strong rheumatism (I. Mitford-Barberton 1934, 76). From the mid-1860s, Mary Barber frequently alluded to a lack of money. See for example (I. Mitford-Barberton 1934, 36); RES, Trimen Correspondence, Box 17, Letter 56.1, Highlands, 26 December 1866; Barber to Hooker, KLAA, Director's Correspondence, Vol. 189, Letter 126, Kimberley, Diamond Fields Girqualand West, 30 June 1874; Barber to Thiselton Dyer, KLAA, Director's Correspondence, Vol. 189, Letter 128a, Kimberley, n.d. [probably between July and October 1876]. In 1870, Frederick departed for Griqualand West, where he hoped to commence a more fruitful career in diamond digging. A year later, his family followed. However, digging proved much less prosperous than anticipated. In 1876, Mary Barber observed that Kimberley was in 'a terrible state', while diamonds were 'not worth digging for' and fetched 'the same price as potatoes', if sellable at all (Barber to Mary Layard Bowker, Kimberly, 23 July 1876. Late Gareth Mitford-Barberton's Private Family Archive, Serial No 019). In the mid-1870s, the Barbers' claim had been worked out. They reached blue ground-a layer of non-oxidised kimberlite-named after the weathered kimberlite which was coloured yellow by 
limonite, and which was hard to mine and less lucrative than the yellow ground - and was generally thought not to be diamondiferous. They thus turned to a new endeavour to support themselves by buying a soda water and ginger ale factory. At first, the factory prospered and Frederick estimated the profits between 70 and $75 \%$ if customers returned the bottles. Due to increasing competition, however, they soon had to lower their prices by $10 \%$ and, again, by a further $10 \%$ a few months later. Moreover, when gold was discovered in other parts of the Transvaal, many diggers decided to seek their fortunes elsewhere and leave Kimberley, which further diminished the Barbers' income significantly. They tried to sell the factory in March 1875, presumably in vain. See (Cohen 2011, [page 5 out of 22 in this chapter manuscript]).

79. See for example (Fourie 1995).

80. M.E. Barber to Amenia Barber, Kimberley, 5 June 1875, extracts only, original letter missing, from Roland Barberton file in Alan Cohen's Private Archive; Barber to Amenia Barber in England, Highlands, 16 November 1868, Late Gareth Mitford-Barberton's Private Family Archive, Serial No 015. See (Hammerton 1910).

81. M. E. Barber to Amenia Barber, Kimberley, 5 June 1875, Roland Barberton archive, copy in Alan Cohen's Archive. Extracts only, original letter missing, from Roland Barberton file; M. E. Barber to Amenia Barber, Highlands, 16 November 1868, Late Gareth Mitford-Barberton's Private Family Archive, Serial No 015. Amenia was the daughter of Frederick's brother Henry, who had immigrated to the US as a missionary. She visited and stayed with her uncle Alfred in Bristol, England, for a while. In 1859, Amenia had visited the Barbers on Highlands, and Mary Barber had immediately taken to her. They regularly wrote to each other thereafter, and Barber frequently asked her niece to visit her again. Amenia never married.

82. (Barber 1878, 30-31). She had written the paper in 'such a dull uninteresting old place' and asked Trimen to help with classification: RES, Trimen Correspondence, Box 18, Letter 101, Kimberley, 2 November 1877.

83. RES, Trimen Correspondence, Box 18, Letter 101, Kimberley, 2 November 1877.

84. As a traveller to Du Toit's Pan confirmed anecdotally when recalling having not seen a single white woman on his trip in 1871 (Rall 2002, 15). It is, thus, no coincidence that Barber's heightened awareness of women's subordination in colonial society and the expression of her most overtly racist sentiments coincided. As seen in Chap. 7.

85. (Selous 1907, 446); (Millais 1919, 125).

86. Barber wrote sarcastically in a letter how 'its a mercy' that one of her sisters-in-law had a sister of her own to help with her pregnancy 'or I should 
have been obliged to have offered her my services and you know how fond I am of that sort of thing'. Mary Barber To Major John Mitford Bowker, Care of David Standen Esq. Grahams Town, Portlock near Graff Reinet [The Rubige farm since ca. 1838], 10 March 1847, HM, SM 5325(16).

87. (McClintock 1995, 276). NELM: 1973.422.19; 1976.13.1; 1997.12.1.1.1. Olive Schreiner, Diamond fields, Chap. 2; only a story, of course [unfinished 1872-1873?], transcriptions of manuscript, original in Cradock Public Library.

88. M. E. Barber to Amenia Barber, Kimberley, 5 June 1875, Roland Barberton archive, copy in Alan Cohen's Archive. Extracts only, original letter missing, from Roland Barberton file.

89. At that time she was most likely already pregnant. Their first son Frederick Alexander Hope Baillie was born on 29 September 1879.

90. Mary Layard inherited her middle name from her godfather, Edgar Leopold Layard.

91. (G. Mitford-Barberton 2006, 49).

92. M. E. Barber to Mary Layard Bowker, Malvern Station, 2 September 1888, Banbury, Late Gareth Mitford-Barberton's Private Family Archive, Serial No 053 .

93. (G. Mitford-Barberton 2006, 55).

94. Barber recalled the original poem inaccurately: 'Mid sullen calm, and silent bay,/ Unseen to drop by dull decay; -/Better to sink beneath the shock/ Than moulder piecemeal on the rock!'. George Gordon Byron, "The Giaour: A Fragment of a Turkish Tale" (1813), in (Galt 1837, $223)$.

95. M. E. Barber to M. L. Bowker, Woods Hotel, 28 November 1889, this letter is incomplete and only the first page survived. Late Gareth MitfordBarberton's Private Family Archive, Serial No 069.

96. Walker in (Walker 1990, 322).

97. http://www.s2a3.org.za/bio/Biograph_final.php?serial=324, date accessed 3 March 2016.

98. In 1890, Hal Barber had become engaged to a woman called Phyllis, surname not mentioned by Mitford-Barberton. However, when her face appears to have become severely scarred-perhaps by smallpox, which was endemic throughout Africa at the time, or by burns-the engagement was cancelled. Mary Layard had also been previously engaged, although relatives never mentioned this relationship and no further details are recorded. These previous engagements may explain the relatively mature age at which they married each other. They were married in Bathurst on 28 March 1894 (G. Mitford-Barberton 2006, 58, 63).

99. The nature of her previous scientific collaborations with the amaXhosa and amaFengu on Tharfield as well as with the Khoekhoen, San and Kikuyu people is not known. 
100. (Rappoport 2012, 144).

101. (McClintock 1995, 286-288), quote: Schreiner, Letters, 178, quoted by McClintock p. 286, capitals in McClintock.

102. Schreiner argued that among the majority of species, 'the female form exceeds the male in size and often in predatory nature. Nor are parenting tasks inherently female in nature.' (McClintock 1995, 291).

103. (Schreiner 1883, 227).

104. English spelling of Afrikaans kokkewiets.

105. Both sexes look alike. Their small sexual dimorphism must also have fascinated Schreiner.

106. (Schreiner 1911, 4-5).

107. (Schreiner 1911, 5). For Schreiner, the equal treatment of females/ women and males/men as well as collaboration between the sexes in a Lamarckian sense improves the condition of the entire species.

108. Tracing this argument in my Kronos article, the Swiss science journalist Urs Hafner interviewed me for a short article in the Swiss National Science Foundation's research magazine, Horizonte, in June 2016. The title of the draft version of his article was 'Of birds and humans' before he changed this to 'Learning gender equality from birds' (my translations) in the published version without informing me. This title wrongly suggests that Barber, like Schreiner, reached the conclusion that gender relations among humans were unequal from her observations of birds (Hammel 2015); 'Von Vögeln und Menschen', Private Correspondence, Hafner to Hammel, 22 March 2016; (Hafner 2016).

109. Vinago delalandei, Salv. (Delalande's green pigeon), two males?, History Museum, Albany Museum Complex, Art Store no 17; Upupa Africana, Bechst. (South African hoopoe), two females?, History Museum, Albany Museum Complex, Art Store no 13. (Schonland 1904, 101-102). For a reproduction of both images, see (Hammel 2015, 106) and the cover of Kronos 41:1 (2015).

110. (Schonland 1904, 101-102).

111. Thanks to Adrian Craig, ornithologist at Rhodes University, for all his insights.

112. See Figures 6 and 7 in (Hammel 2015, 106).

113. Barber may thereby have reacted to the contemporary pathologising of homosexuality in Europe, where homosexually was illegal. Homosexuality led to trials like that of the author Oscar Wilde in 1895. Barber's continued criticism of marriage and her negative comments about men have led some of my colleagues at conferences to question whether she was a lesbian. Others pondered whether she was transgender, probably associating her with James Miranda Stuart Barry, who was born Margaret Ann Bulkley (1795?-1865) and who, disguised as a man, became a military surgeon in the British Army at the Cape. There is no evidence for either 
of these assumptions and in the few remaining sources where Barber writes about relationships she does not address homosexuality. (A case in point being at the graduate workshop "Vorstellungen von Naturräumen", Basel Graduate School of History, Basel, 18 December 2014; discussions with various academics in Makhada/Grahamstown). See for example (Du Preez and Dronfield 2016); (Beukes 2005, 34-46); (Holmes 2002).

114. Two Zulu women in Maritzburg (Pietermaritzburg), initiating Chapter 20, MS 10560, (C) Cory Library.

115. The English writer and modernist Virginia Woolf later criticised the heterosexual structuring of bourgeois gender regimes when attacking the notion of the existence of only two genders in her essay A Room of One's Own (1929).

116. Alan Cohen's Private Archive, "Nature Tales": 'The Dove and the Sparrow', 'The Rhinoceros and the Rhinoceros Birds', 'The Small Birds and the Owl', 'The Wood Robin', 'The Starlings', 'The Swallows, 'A Tale of the Locusts and the Locust-Birds, 'The Dove and the Grey Sand Piper's Nest, 'The Tame Blue Crane', n.d., n.p.

117. Barber to Mary Anne Bowker (her brother John Mitford's wife), Modderfontein, 15 November 1847, HM, SM 5325 (18). This is exaggerated as she had spent many years to decades on Tharfield, and would later live for extended periods of time on Highlands and in Kimberley.

118. RES, Trimen Correspondence, Box 18, Letter 105, Kimberley, 11 April 1878.

119. RES, Trimen Correspondence, Box 18, Letter 114, Grahamstown, 30 March 1882.

120. Darwin to Caroline A. Kennard, 9 January 1882, Darwin Correspondence Project, Letter 13,607.

121. (Neeley 2001, 60).

122. Her second husband, William Somerville, had been a garrison-surgeon who had been stationed at the Cape between 1799 and 1802. He wrote a paper on the sexual characteristics of Khoekhoe women, which he deposited at the Royal Society in 1806 and published in 1816. Somerville in: (Somerville 1979, 236-241).

123. His wedding present was a small library of the best French mathematical books then available, while he would regularly go to local libraries to procure for her any books which she needed as well as encourage her to move in the political and scientific circles in London in which she could best promote her work (Jim Secord 2011).

124. One of the first colleges for women, Somerville Hall, Oxford, was founded in 1879 and named after her (Jim Secord 2011).

125. RES, Trimen Correspondence, Box 18, Letter 105, Kimberley, 11 April 1878.

126. (Neeley 2001, 58). 
127. (Jim Secord 2011).

128. Quoted in (Bonyhady 2000, 133), italics in the original.

129. Barber, “A Plea for Insectivorous Birds”, HM, SM 5501 (46), 13.

130. Barber, The Graham's Town Journal, 20 July 1886.

131. Barber, "A Plea for Insectivorous Birds", HM, SM 5501 (46), 12.

132. Barber to J. D. Hooker, KLAA, Directors' Correspondence, Vol. 189, Letter 114, Highlands, 9 May 1867.

133. (Merchant 2010, 11). In the US, men such as the clergyman Henry Ward Beecher were convinced that 'only women could halt the trade by halting the demand for feathers', while G. E. Gordon, president of the American Humane Society, demanded that women 'be educated in the crime perpetrated by their feather-wearing sin'. Quoted in (Merchant 2010, 11-12).

134. (Merchant 1996, 115, 128, 136); (Gates 1998, 114-124).

135. (Kofalk 1989, 150).

136. (Kofalk 1989, 51).

137. See (Fourie 1995); (Hicks 1900).

138. She seems not to have been aware that a group of Voortrekker women in Natal had demanded political rights in as early as 1843 .

139. (Walker 1990, 317-318, 321-322).

140. From 1869, colleges for women such as Girton College and Newnham College, Cambridge, and the London School of Medicine for Women were opened, but in many of these, women could not read for the same degrees as men. Newham, for instance, did not allow women to obtain the same degrees as men until 1949 (Christensen Nelson 2004, xxii). South African Maria Wilman (1867-1957) entered Newham College Cambridge in 1885 and completed a natural science tripos in geology, mineralogy and chemistry in 1888 and an MA in botany in 1895. But, as women also did not receive formal degrees until the 1930s, she only received her diploma in November 1933. (2012), The African Rock Art Digital Archive. http://www.sarada.co.za/people_and_institutions/ researchers/maria_wilman/, date accessed 30 June 2016.

141. (Christensen Nelson 2004, xii). See for example (L. Becker 1867).

142. (Phillips 2003, 134).

143. The English women's movement had in turn mainly been influenced by developments in the US. See for example: (Taylor and Mill 1851).

144. (Walker 1990, 313, 322-324).

145. They thereby promoted the argument that William Thompson had already made in 1825 in his 'Appeal of One Half of the Human Race, Women, Against the Pretensions of the Other Half, Men, to Retain Them in Political, and Thence in Civil and Domestic Slavery'.

146. (Phillips 2003, 5). 
147. 'The issue of the same and the different in relation to equality', the socalled equality versus difference paradox, still divides the feminist movement into diverse strands today (Stepan 2000, 62).

148. (Schwarz 2011).

149. (Schwarz 2011).

150. Woolf (1920), reprinted in (Woolf 1978, 337-338); (Black 2004, 103).

151. Barber, Wanderings, Vol. 2, MS 10560 (b), 77.

152. (Barber 1880, 203-204).

153. Fourie, 87 quoted in (Letcher 1999, 3).

154. Ward, 84 quoted in (Letcher 1993, 314).

155. (Cock 1990, 83).

156. (Cock 1990, 85-94).

157. The Irish military surgeon James Miranda Stuart Barry (c. 1789 to 17991865, born Margaret Ann Bulkley), who served in Cape Town for the British Army, preceded Waterston in this regard, but it only became known after his death that Barry was in fact a woman.

158. (Cock 1990, 90-91, 93-94). See also (Bean and van Heyningen 1983); (van Heyningen 1996).

159. See (Ware 2015, "Part Three: Britannia's Other Daughters: Feminism in the Age of Imperialism").

160. This is a tendency that can also be observed among European feminists in the twentieth century, such as the French philosopher Simone de Beauvoir (1908-1986) or the Swiss lawyer and author Iris von Roten (1917-1990) who both had Western, white, middle-class heterosexual women in mind in their writings. See for example (Gines 2014); (Maihofer 2009).

161. Similarly, studies on nature conservationists such as John Muir in the US or Louisa Anne Meredith in Tasmania have shown how, due to racist attitudes, they silenced the respective influence of Native Americans and Tasmanians on their philosophies of human-nature interplay. See for example (Merchant 2003); (Standish and Grimshaw 2007).

162. (McClintock 2001, 26, 27).

163. This was only followed by a single volume of poems-(Barber 1898)— and a posthumous publication-(Barber 1903).

164. (Walker 1990, 329).

165. (Walker 1990, 337, 338, 340).

166. (Walker 1990, 341-342).

167. (Walker 1990, 343).

168. (Walker 1990, 344). Also see (Strobel 1991, xi).

169. Merle Patchett, Murderous Millinery, Fashioning Feathers (2011), https://fashioningfeathers.info/murderous-millinery date accessed 4 October 2016. 


\section{REFERENCES}

Ashley, Melissa. 2016. The Birdman's Wife. Melbourne: Affirm Press.

Bank, Andrew. 2016. Pioneers of the Field: South Africa's Women Anthropologists. Cambridge: Cambridge University Press.

- 2019. 'Bridging the Gap Between the Intellectual and the Human': The Awkward Biography of Anthropologist and Scholar-Activist Iona Simon Mayer (1923-). African Studies 78: 267-289.

Barber, M.E. 1878. On the Peculiar Colours of Animals in Relation to Habits of Life. Transactions of the South African Philosophical Society 4: 27-45.

- 1880. Locusts and Locust Birds. Transactions of the South African Philosophical Society 1: 193-218.

- 1898. The Erythrina Tree and Other Verses. London: Printed for private circulation.

- 1903. Stapelias. Kew Bulletin: 17-19.

- 1962. Wanderings in South Africa: An Account of a Journey from Kimberley to Cape Town and on to Natal. Quarterly Bulletin of the South African Museum 17: 39-53, 61-74-39-53103-116.

Bayer, Adolph W. 1979. Flower Paintings of Katharine Saunders: Botanical and Biographical Notes and Explanations. Tongaat: Tongaat Group.

Bean, Lucy, and Elizabeth van Heyningen. 1983. The Letters of Jane Elizabeth Waterston 1866-1905. Cape Town: Van Riebeeck Society.

Becker, Lydia Ernestine. 1864. Botany for Novices: A Short Outline of the Natural System of Classification of Plants. London: Whittaker and Co.

Becker, Lydia. 1867. Female Suffrage. The Contemporary Review IV: 307-316.

Beer, Gillian. 2000. Darwin's Plots: Evolutionary Narrative in Darwin, George Eliot, and Nineteenth-Century Fiction. 2nd ed. Cambridge: Cambridge University Press.

Beinart, William. 1998. Men, Science, Travel and Nature in the Eighteenth and Nineteenth-Century Cape. Journal of Southern African Studies 24: 775-799.

Beukes, Lauren. 2005. Maverick: Extraordinary Women from South Africa's Past. Cape Town: Struik Publishers.

Black, Naomi. 2004. Virginia Woolf as Feminist. Ithaca/London: Cornell University Press.

Blackburn, Helen. 1902. Women's Suffrage: A Record of the Women's Suffrage Movement in the British Isles with Biographical Sketches of Miss Becker. London: Williams \& Norgate.

Bonyhady, Tim. 2000. The Colonial Earth. Melbourne: Melbourne University Press.

Bowdler Sharpe, Richard. 1884. The Birds of South Africa, Part VI. London: Bernhard Quarith.

Chisholm, Alec H. 1944. The Story of Elizabeth Gould. Melbourne: The Hawthorn Press.

Christensen Nelson, Carolyn. 2004. Literature of the Women's Suffrage Campaign in England. Ontario: Broadview Press. 
Cock, Jacklyn. 1990. Domestic Service and Education for Domesticity: The Incorporation of Xhosa Women into Colonial Society. In Women and Gender in Southern Africa to 1945, ed. Cherryl Walker, 76-96. Cape Town/London: David Philip/James Currey.

Cohen, Alan. 2000. Mary Elizabeth Barber, Some Early South African Geologists and the Discoveries of Gold. South African Journal of Economic History 15: 1-19.

- 2011. In a Quiet Way: The Life of Mary Elizabeth Barber, South Africa's First Lady Natural Historian 1818-1899.

- 2015. In a Quiet Way: The Life of Mary Elizabeth Barber, South Africa's First Lady Natural Historian 1818-1899.

Creese, Mary R.S., and Thomas M. Creese. 2010. South African, Australian, New Zealand, and Canadian Women in Science, Nineteenth and Early Twentieth Centuries, A Survey of Their Contributions, Ladies in the Laboratory 3. Lanham/Toronto/Plymouth: The Scarecrow Press Inc..

Daston, Lorraine, and Gregg Mitman. 2006. Thinking with Animals: New Perspectives on Anthropomorphism. New York: Columbia University Press.

Du Preez, Michael, and Jeremy Dronfield. 2016. Dr James Barry: A Woman Ahead of Her Time. La Vergne: Oneworld Publications.

Endersby, Jim. 2009. Sympathetic Science: Charles Darwin, Joseph Hooker, and the Passions of Victorian Naturalists. Victorian Studies 51: 299-320.

Foucault, Michel. 1984. Of Other Spaces: Utopias and Heterotopias. Architecture, Mouvement, Continuité 5: 46-49.

- 2006. Von anderen Räumen. In Raumtheorie: Grundlagentexte aus Philosophie und Kulturwissenschaften, ed. Jörg Dünne and Stephan Günzel, 317-329. Frankfurt a.M.: Suhrkamp.

Fourie, Fiona. 1995. A 'New Woman' in the Eastern Cape. English in Africa 22: 70-88.

Fry, C. Hilary, and Kathie Fry. 1999. Kingfishers, Bee-Eaters and Rollers, with Illustrations by Allan Harris. Princeton: Princeton University Press.

Galaty, John G. 1998. The Maasai Ornithorium: Tropic Flights of Avian Imagination in Africa. Ethnology 37: 227-238.

Galt, John. 1837. The Complete Works of Lord Byron, Now First Collected and Arranged, and Illustrated, in One Volume. Paris: Baudry's European Library.

Gates, Barbara T. 1998. Kindred Nature: Victorian and Edwardian Women Embrace the Living World. Chicago: The University of Chicago Press.

Gines, Kathryn T. 2014. Comparative and Competing Frameworks of Oppression in Simone de Beauvoir's The Second Sex. Graduate Faculty Philosophy Journal 35: 251-273.

Glen, Hugh Francis, and Gerrit Germishuizen. 2010. Botanical Exploration of Southern Africa. 2nd ed. Strelitzia 26. Pretoria: South African National Biodiversity Institute.

Gunn, Mary Davidson, and Leslie Edward Wostall Codd. 1981. Botanical Exploration of Southern Africa. Cape Town: A. A. Balkema. 
Gutsche, Thelma. 1972. Mary Elizabeth Barber. In Dictionary of South African Biography, ed. W.J. Kruger and D.W. De Kock, vol. 2, 26-27. Cape Town: Tafelberg-Uitgewers Ltd.

Guy, Jeff. 1983. The Heretic: A Study of the Life of John William Colenso, 1814-1883. Johannesburg: Ravan Press.

- 1997. Class, Imperialism and Literary Criticism: William Ngidi, John Colenso and Matthew Arnold. Journal of Southern African Studies 23: 219-241.

- 2001. The View Across the River: Harriette Colenso and the Zulu Struggle Against Imperialism. Cape Town: New Africa Books.

Hafner, Urs. 2016. Von den Vögeln die Gleichberechtigung gelernt. Schweizerischer Nationalfonds - Akademien Schweiz: Horizonte. Das Schweizer Forschungsmagazin, 109: 37.

Hamlin, Kimberly A. 2014. From Eve to Evolution: Darwin, Science, and Women's Rightsin Gilded Age America. Chicago/London: The University of Chicago Press. Hammel, Tanja. 2015. Thinking with Birds: Mary Elizabeth Barber's Advocacy for Gender Equality in Ornithology. Kronos 41: 85-111.

2016. Mary Barber's Expedition Journal: An Experimental Space to Voice Social Concerns. In Expedition as Experiments: Practising Observation and Documentation, ed. Marianne Klemun and Ulrike Spring, 121-140. Basingstoke/New York: Palgrave Macmillan.

Hammerton, John Alexander, ed. 1910. Mr. Punch's Book of Love: Being the Humours of Courtship and Matrimony, Illustrated by John Leech. London: The Educational Book Co. Ltd..

Harley, Alexis. 2014. Darwin's Ants: Evolutionary Theory and the Anthropomorphic Fallacy. In Representing the Modern Animal in Culture, ed. Jeanne Dubino, Ziba Rashidian, and Andrew Smyth, 103-118. New York: Palgrave Macmillan.

Hausen, Karin. 1976. Die Polarisierung der 'Geschlechtscharaktere' - Eine Spiegelung der Dissoziation von Erwerbs- und Familienleben. In Sozialgeschichte der Familie in der Neuzeit Europas. Neue Forschungen, ed. Werner Conze, 363-393. Stuttgart: Klett.

Hicks, Beatrice. 1900. The Cape as I Found It. London: Elliot Stock.

Hilton-Barber, David. 2014. The Saint, the Surgeon and the Unsung Botanist ... and a Race-Horse Breeder to Boot. A Tribute to My Remarkable Ancestors. Makhado/Limpopo: Footprints Press.

Holmes, Rachel. 2002. Scanty Particulars: The Scandalous Life and Astonishing Secret of James Barry, Queen Victoria's Most Eminent Military Doctor. New York: Random House.

Jacobs, Nancy J. 2016. Birders of Africa: History of a Network. New Haven/ London: Yale University Press.

Jann, Rosemary. 1994. Darwin and the Anthropologists: Sexual Selection and Its Discontents. Victorian Studies 37: 287-306. 
Jim Secord. 2011. Mary Somerville and the Empire of Nineteenth Century Science, Royal Society. https://www.youtube.com/watch?v=KBTeXabfqtw, 28 October 2011. Accessed 5 July 2016.

Kelly, Audrey. 1992. Lydia Becker and the Cause. Lancaster: Centre for NorthWest Regional Studies, University of Lancaster.

Kent, Susan Kingsley. 1987. Sex and Suffrage in Britain, 1860-1914. Princeton: Princeton University Press.

Kitchin, S.B. 1912. A History of Divorce. London: Chapman \& Hall.

Kofalk, Harriet. 1989. No Woman Tenderfoot: Florence Merriam Bailey, Pioneer Naturalist. College Station: Texas A \& M University Press.

Kosek, Jake. 2010. Ecologies of Empire: On the New Uses of the Honeybee. Cultural Anthropology 25: 650-678.

Kupper, Patrick. 2012. Wildnis schaffen, eine Transnationale Geschichte des Schweizerischen Nationalparks. Bern/Stuttgart/Wien: Haupt.

Layard, Edgar Leopold. 1867. The Birds of South Africa: A Descriptive Catalogue of All the Known Species Occurring South of the 28th Parallel of South Latitude. Cape Town/London: Juta/Longman, Green \& Co.

Lear, Linda. 2007. Beatrix Potter - The Extraordinary Life of a Victorian Genius. London: Penguin Books.

Le-May Sheffield, Suzanne. 2001. Revealing New Worlds. Three Victorian Women Naturalists. London/New York: Routledge.

Letcher, Valerie. 1993. Feminism and Marginality on the Frontier in the Works of Harriet Ward, 1:311-1:319. Port: Elizabeth/Potchefstroom.

- 1999. Harriet Ward: Trespassing Beyond the Borders. English in Africa 26: 1-16.

Levine, George. 2006. Darwin Loves You: Natural Selection and the Re-enchantment of the World. Princeton: Princeton University Press.

Lévi-Strauss, Claude. 1966. The Savage Mind. Chicago: The University of Chicago Press.

Maihofer, Andrea. 2009. Simone de Beauvoir und Iris von Roten. Die Frau als eigenständiges Subjekt. Olympe: Feministische Arbeitshefte zur Politik, Offene Worte: Zur Aktualität von Iris von Rotens "Frauen im Laufgitter" 28: 121-129.

Mathie, Nerina. 1998. Nerina Mathie, Man of Many Facets: Atherstone Dr W. G. 1814-1898: Pseudo-Autobiography, Vol. 2, (Grahamstown: privately published, 1998). Vol. 2. Grahamstown: Private Publication.

Mavhunga, Clapperton Chakanetsa. 2011. Vermin Beings: On Pestiferous Animals and Human Game. Social Text 29: 151-176.

McClintock, Anne. 1995. Imperial Leather: Race, Gender and Sexuality in the Colonial Contest. London: Routledge.

- 2001. Double Crossings: Madness, Sexuality and Imperialism. In The 2000 Garnett Sedgewick Memorial Lecture. Vancouver: Ronsdale Press. 
McKenzie, Kirsten E. 1997. Gender and Honour in Middle-Class Cape Town: The Making of Colonial Identities 1828-1850. $\mathrm{PhD}$ thesis, University of Oxford, Oxford.

Merchant, Carolyn. 1996. Earthcare: Women and the Environment. New York: Routledge.

-2003. Shades of Darkness: Race and Environmental History. Environmental History 8: 380-394.

- 2010. George Bird Grinnell's Audubon Society: Bridging the Gender Divide in Conservation. Environmental History 15: 3-30.

Millais, John Guille. 1919. Life of Frederick Courteney Selous, Second Impression. New York: Longmans, Green and Co.

Mitchell, William John Thomas. 1986. Iconology: Image, Text, Ideology. Chicago: The University of Chicago Press.

- 1994. Picture Theory. Chicago: The University of Chicago Press.

Mitford-Barberton, Ivan. 1934. The Barbers of the Peak. A History of the Barber, Atherstone, and Bowker Families. Oxford: Oxford University Press.

Mitford-Barberton, Gareth. 2006. Pioneer Spirit. Victoria: Trafford Publishing.

Neeley, Kathryn A. 2001. Mary Somerville: Science, Illumination, and the Female Mind. Cambridge: Cambridge University Press.

Parker, Joan E. 2001. Lydia Becker's 'School for Science': A Challenge to Domesticity. Women's History Review 10: 629-650.

Paxton, Nancy L. 1991. George Eliot and Herbert Spencer: Feminism, Evolutionism, and the Reconstruction of Gender. Princeton: Princeton University Press.

Phillips, Melanie. 2003. The Ascent of Woman: A History of the Suffragette Movement and the Ideas Behind it. London: Little, Brown.

Raffles, Hugh. 2001. The Uses of Butterflies. American Ethnologist 28: 513-548. . 2013. Insektopädie (aus dem Englischen übersetzt von Thomas Sechstag). Berlin: Matthes \& Seitz.

Rall, Maureen. 2002. Petticoat Pioneers: The History of the Pioneer Women Who lived on the Diamond Fields in the Early Years. Kimberley: Kimberley Africana Library.

Rappoport, Jill. 2012. Giving Women: Alliance and Exchange in Victorian Culture. Oxford: Oxford University Press.

Richards, Evelleen. 1983. Darwin and the Descent of Woman. In The Wider Domain of Evolutionary Thought, ed. David Oldroyd and Ian Langham, 57-111. Dordrecht: Reidel.

Ritchie, David G. 1909. Darwinism and Politics. 2nd ed. New York: Charles Scribner's Sons.

Russett, Cynthia Eagle. 1989. Sexual Science: The Victorian Construction of Womanhood. Cambridge: Harvard University Press.

Schonland, Selmar. 1904. Biography of the Late Mrs F.W. Barber, and a List of Her Paintings in the Albany Museum. Records of the Albany Museum 1: 95-108. 
Schreiner, Olive. 1883. The Story of an African Farm: A Novel. Chicago: M. A. Donohue and Co.

- 1911. Woman and Labour. 3rd ed. New York: Frederick A. Stokes.

Schwarz, Bill. 2011. The White Man's World, Memories of Empire. Vol. 1. Oxford: Oxford University Press.

Selous, Frederick Courteney. 1907. A Hunter's Wanderings in Africa: Being a Narrative of Nine Years Spent Amongst the Game of the Far Interior of South Africa. London/New York: Macmillan and Co.

Shteir, Ann B., and Bernard Lightman, eds. 2006. Figuring It Out: Science, Gender, and Visual Culture. Lebanon: Dartmouth College Press.

Sinclair, Ian, and Ian Davidson. 2006. Southern African Birds: A Photographic Guide. 2nd ed. Cape Town: Struik Publishers.

Smith, Jonathan. 2001. Charles Darwin, John Gould, and the Picturing of Natural Selection. Book Collector 50: 51-76.

- 2006a. Darwin's Birds. In Charles Darwin and Victorian Visual Culture, 92-137. Cambridge: Cambridge University Press.

-2006b. Picturing Sexual Selection: Gender and Evolution of Ornithological Illustration in Charles Darwin's Descent of Man. In Figuring It Out: Science, Gender, and Visual Culture, ed. Ann B. Shteir and Bernard V. Lightman, 85-109. Lebanon: Dartmouth College Press.

- 2007. Gender, Royalty, and Sexuality in John Gould's Birds of Australia. Victorian Literature and Culture 35: 569-587.

Somerville, William. 1979. On the Structure of Hottentot Women. In William Somerville's Narrative of His Journeys to the Eastern Cape Frontier and to Lattakoe 1799-1802, ed. Edna Brownlow and Frank Brownlow, vol. 10, 236-241. 2. Cape Town: Van Riebeeck Society.

Standish, Ann, and Patricia Grimshaw. 2007. Making Tasmania Home: Louisa Meredith's Colonizing Prose. Frontiers: A Journal of Women Studies, Domestic Frontiers: The Home and Colonization 28: 1-17.

Stein, Sarah Abrevaya. 2010. Plumes: Ostrich Feathers, Jews, and a Lost World of Global Commerce. New Haven: Yale University Press.

Stepan, Nancy Leys. 2000. Race, Gender, Science and Citizenship. In Cultures of Empire: A Reader. Colonizers in Britain and the Empire in the Nineteenth and Twentieth Centuries, ed. Catherine Hall, 61-86. New York: Routledge.

Stoler, Ann Laura. 1991. Carnal Knowledge and Imperial Power: Gender, Race, and Morality in Colonial Asia. In Gender at the Crossroads of Knowledge: Feminist Anthropology in the Postmodern Era, ed. Micaela die Leonardo, 51-101. Berkeley/Los Angeles/London: University of California Press.

- 2002. Carnal Knowledge and Imperial Power: Race and the Intimate in Colonial Rule. London: University of California Press.

Strobel, Margaret. 1991. European Women and the Second British Empire. Bloomington: Indiana University Press. 
Taylor, Harriet, and John Stuart Mill. 1851. Enfranchisement of Women. Westminster Review 55: 289-311.

van Heyningen, Elizabeth. 1996. Jane Elizabeth Waterston - Southern Africa's First Woman Doctor. Journal of Medical Biography 4: 208-213.

Vicinus, Martha, ed. 1977. A Widening Sphere: Changing Roles of Victorian Women. Bloomington/London: Indiana University Press.

Walker, Cherryl, ed. 1990. Women and Gender in Southern Africa to 1945. Cape Town/London: David Philip/James Currey.

Wallace, Robert. 1904. Eleanor Ormerod, Ll. D., Economic Entomologist: Autobiography and Correspondence. London: John Murray.

Ware, Vron. 2015. Beyond the Pale: White Women, Racism, and History. Brooklyn/ London: Verso Books.

White, Alain Campbell, and Boyd L. Sloane. 1937. The Stapelieae. Pasadena: Abbey San Encino Press.

Wollstonecraft, Mary. 1833. A Vindication of the Rights of Woman with Strictures or Political and Moral Subjects. New York: A. J. Matsell.

Woolf, Virginia. 1966. Professions for Women. In Collected Essays by Virginia Woolf, vol. 2, 284-289. London: Hogarth Press.

—. 1978. "The Plumage Bill”, The Woman's Leader, 23 July 1920. In The Diary of Virginia Woolf, Volume Two: 1920-1924, ed. Anne Olivier Bell, 337338. New York: Harcourt Brace Jovanovich.

Yeazell, Ruth Bernard. 1991. Fictions of Modesty: Women and Courtship in the English Novel. Chicago: Chicago University Press.

Open Access This chapter is licensed under the terms of the Creative Commons Attribution 4.0 International License (http://creativecommons.org/licenses/ by $/ 4.0 /$ ), which permits use, sharing, adaptation, distribution and reproduction in any medium or format, as long as you give appropriate credit to the original author(s) and the source, provide a link to the Creative Commons licence and indicate if changes were made.

The images or other third party material in this chapter are included in the chapter's Creative Commons licence, unless indicated otherwise in a credit line to the material. If material is not included in the chapter's Creative Commons licence and your intended use is not permitted by statutory regulation or exceeds the permitted use, you will need to obtain permission directly from the copyright holder.

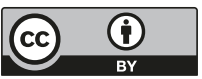

